\title{
MULTIVARIATE FACTOR ASSESSMENT FOR LITHOGENIC AND ANTHROPOGENIC DISTRIBUTION OF MACRO AND TRACE ELEMENTS IN SURFACE WATER. CASE STUDY: BASIN OF THE BREGALNICA RIVER, REPUBLIC OF MACEDONIA
}

\author{
Biljana Balabanova1 $^{1}$, Trajče Stafilov² ${ }^{*}$, Robert Šajn ${ }^{3}$, Claudiu Tănăselia ${ }^{4}$ \\ ${ }^{1}$ Faculty of Agriculture, Goce Delčev University, Krste Misirkov bb, Štip, Republic of Macedonia \\ ${ }^{2}$ Institute of Chemistry, Faculty of Science, Ss Cyril and Methodius University, \\ POB 162, 1000 Skopje, Republic of Macedonia \\ ${ }^{3}$ Geological Survey of Slovenia, Dimičeva ulica 14, 1000 Ljubljana, Slovenia \\ ${ }^{4}$ INCDO-INOE 2000 Research Institute for Analytical Instrumentation (ICIA), Cluj-Napoca, Romania \\ trajcest@pmf.ukim.mk
}

This study presents the spatial distribution of 69 elements in the surface water of the Bregalnica river basin. The concentration of elements was determined using inductively coupled plasma with mass spectrometry (ICP-MS) and inductively coupled plasma - atomic emission spectrometry (ICP-AES). The data summary results were reduced with the application of multivariate factor analysis, whereupon three dominant geochemical associations were obtained: F1 (Ca-K-Mg-Na-Ba-Li-Mn-Sr-V), F2 (Al-Fe) and F3 (Sb). Anthropogenic enrichments of $\mathrm{Pb}$ and $\mathrm{Zn}$ occur in the $\mathrm{Pb}-\mathrm{Zn}$ mine area. The obtained data exceeded the maximum allowed concentrations in accordance with the national regulation for surface water quality. Trace elements including REEs were significantly correlated with the dominant geological formations characteristic of the different sub-regions in the investigated area.

Keywords: heavy metals; spatial distribution; factor analysis; ICP-AES; ICP-MS; Bregalnica river

\section{МУЛТИВАРИЈАНТНА ФАКТОРНА ПРОЦЕНА НА ЛИТОГЕНАТА И АНТРОПОГЕНАТА ДИСТРИБУЦИЈА НА МАКРОЕЛЕМЕНТИ И ЕЛЕМЕНТИ ВО ТРАГИ ВО ПОВРШИНСКИ ВОДИ. ПРЕДМЕТ НА СТУДИЈАТА: СЛИВ НА РЕКАТА БРЕГАЛНИЦА, РЕПУБЛИКА МАКЕДОНИЈА}

Овој труд ја прикажува дистрибуцијата на 69 елементи во површинските води во сливот на реката Брегалница. Содржината на елементите беше одредувана со примена на масената спектрометрија со индуктивно спрегната плазма (ICP-MS) и атомската емисиона спектрометрија со индуктивно спрегната плазма (ICP-AES). Вкупниот број променливи беше редуциран со примена на факторна анализа, при што беа добиени три доминантни геохемиски асоцијации: F1 (Ca-K-Mg-Na-Ba-Li-Mn-Sr-V), F2 (Al-Fe) и F3 (Sb). Утврдени се антропогено зголемени концентрации на $\mathrm{Pb}$ и $\mathrm{Zn}$ во регионот на хидротермално искористување на $\mathrm{Pb}-\mathrm{Zn}$ минерали. Добиените вредности за концентрацијата на овие елементи ги надминуваат максимално дозволените концентрации според националната регулатива за квалитет на површинските води. Елементите во траги, вклучувајќи ги и ретките земји, покажаа значајна корелација со доминантните геолошки формации карактеристични за различни под региони во испитуваната област.

Клучни зборови: тешки метали; просторна дистрибуција; факторна анализа; ICP-AES; ICP-MS; река Брегалница 


\section{INTRODUCTION}

The aquatic environment is one of the four components of the Earth and interconnects with the other components, namely the atmosphere, lithosphere and biosphere. Water is essential for life and acts mostly as a vehicle for the transport of constituents and pollutants (including toxic metals) between these environmental components [1]. Metals and metal compounds may be released into the environment within the lifecycle of metallic products, including several processes such as: mining, extraction, smelting and refining, production, use and disposal, recycling and reuse [2-4]. These chemical compounds may enter the environment either as the main component of the metal product or as impurities during any stage of the lifecycle, especially at the beginning (for example, mining to production) and the end (i.e. disposal) of the cycle [5]. The recent rise in the development of these industries has increased the risk to public health due to heavy metals such as cadmium, lead and chromium [6]. The industrial pollution of heavy metals is often through the discharge of partially treated or untreated effluents, and can pose dangers to the public by contaminating local water sources of drinking water supplies and agricultural irrigation water [7]. The main natural sources of metals in water are chemical weathering of minerals or soil leaching [8]. A general conclusion and the main starting point is that the anthropogenic sources are associated mainly with industrial and domestic effluents, urban storms, water runoff, mining of coal and ore, atmospheric sources, and inputs from the rural area [4]. The analysis of dissolved metals in water is a useful tool for assessing the state of pollution in a particular ecosystem, reflecting its specific degree of contamination [9-11].

The availability of highly sensitive multielement analytical techniques, such as inductively coupled plasma - mass spectrometry (ICP-MS), provides a method for the quantitative determination of a wide variety of trace elements in water at indigenous concentration levels without preconcentration [12]. Elements in higher concentrations, such as calcium, magnesium, and sodium, as well as elements that are difficult to determine by ICP-MS, such as iron, are readily determined by atomic emission spectrometry with the inductively coupled plasma (ICP-AES) technique [12].

Toxic heavy metals have been a universal pollution issue around the world whenever and wherever heavy manufacturing industries are on the rise, and can dominate a country's economy during their rapid development. The Republic of
Macedonia does not diverge from this global framework of pollution of the environment with certain toxic metals. The studies implemented so far show that certain areas of the territory of the Republic of Macedonia are blighted by the anthropogenic introduction of high levels of different chemical elements in the environment [13-22].

The basin of the Bregalnica river is an interesting region from the aspect of its specific geology (for lithological distribution of elements), but there are several significant sources of potentially toxic metals and other chemical elements in the environment, which contribute to the anthropogenic influence of the distribution of these elements [23]. The Bregalnica river basin is characterized by the occurrence of lead and zinc mineralization and exploitation ("Zletovo" and "Sasa" mines), copper mineralization and exploitation ("Bučim" mine) and $\mathrm{Fe}$ mineralization and former exploitation ("Damjan" mine). Local-scale investigation can provide information on the specific distribution of chemical elements in water from significant hydrographic factors, and thus follow their positive or negative impact on the environment and humans.

The main goal of this study was to assess the dominant anthropogenic and lithogenic markers from a total of 69 analyzed elements: Ag, As, Al, $\mathrm{Au}, \mathrm{B}, \mathrm{Ba}, \mathrm{Be}, \mathrm{Bi}, \mathrm{Br}, \mathrm{Ca}, \mathrm{Cd}, \mathrm{Ce}, \mathrm{Co}, \mathrm{Cr}, \mathrm{Cs}, \mathrm{Cu}$, Dy, Er, Eu, Fe, Ga, Gd, Ge, Hf, Hg, Ho, I, In, Ir, $\mathrm{K}, \mathrm{La}, \mathrm{Li}, \mathrm{Lu}, \mathrm{Mg}, \mathrm{Mn}, \mathrm{Mo}, \mathrm{Na}, \mathrm{Nb}, \mathrm{Nd}, \mathrm{Ni}, \mathrm{Os}, \mathrm{P}$, $\mathrm{Pb}, \mathrm{Pd}, \mathrm{Pr}, \mathrm{Pt}, \mathrm{Rb}, \mathrm{Re}, \mathrm{Rh}, \mathrm{Ru}, \mathrm{Sb}, \mathrm{Sc}, \mathrm{Se}, \mathrm{Sm}, \mathrm{Sn}$, $\mathrm{Sr}, \mathrm{Ta}, \mathrm{Tb}, \mathrm{Te}, \mathrm{Ti}, \mathrm{Th}, \mathrm{Tl}, \mathrm{Tm}, \mathrm{V}, \mathrm{W}, \mathrm{Y}, \mathrm{Yb}, \mathrm{Zn}$ and $\mathrm{Zr}$ - in river water from the Bregalnica river basin. As well as the multivariate extraction of the geochemical elements associations, the pollution effects were examined in the area of very old geological formation. Thus, this work presents the first attempt to characterize the lithogenic vs. anthropogenic inputs in water environments.

\section{MATERIAL AND METHODS}

\subsection{Investigated area}

The investigated area includes the basin of the Bregalnica river which is in the eastern part of the Republic of Macedonia. The investigated area covers $\sim 90 \mathrm{~km}(\mathrm{~W}-\mathrm{E}) \times 50 \mathrm{~km}(\mathrm{~S}-\mathrm{N})$ and thus a total of $\sim 4000 \mathrm{~km}^{2}$, within the following geographic coordinates N: $41^{\circ} 27^{\prime}-42^{\circ} 09^{\prime}$ and E: $22^{\circ} 55^{\prime}-$ $23^{\circ} 01^{\prime}$ (Fig. 1). The area is characterized by two valleys - Maleševo and Kočani valleys. The Maleševo valley represents the upper course of the Bregalnica river, where the river source is also located, with an average altitude of 700-1140 m. 
The valley is enclosed by the Maleševo Mountains in the east, by the Mt. Ogražden in the southsoutheast, and Plačkovica and Obozna mountains in the west. The average annual precipitation is about $500 \mathrm{~mm}$, with significant variations from year to year, as well as in the different sub-regions [24]. The precipitation is mostly related to and conditioned by Mediterranean cyclones [24]. During the summer period, the region is most often found in the centre of subtropical anticyclones, which cause warm and dry summers. From the central area of the region, as the driest area, the average annual precipitation increases in all directions, because of either the increase in the influence of the Mediterranean climate or the increase in altitude [24]. The annual total number of hours of sunshine per day is about 6.0 hours in this area. In the region about ten climatic-vegetation soil areas are distinguished, with heterogeneous climate, soil and vegetation characteristics [24].

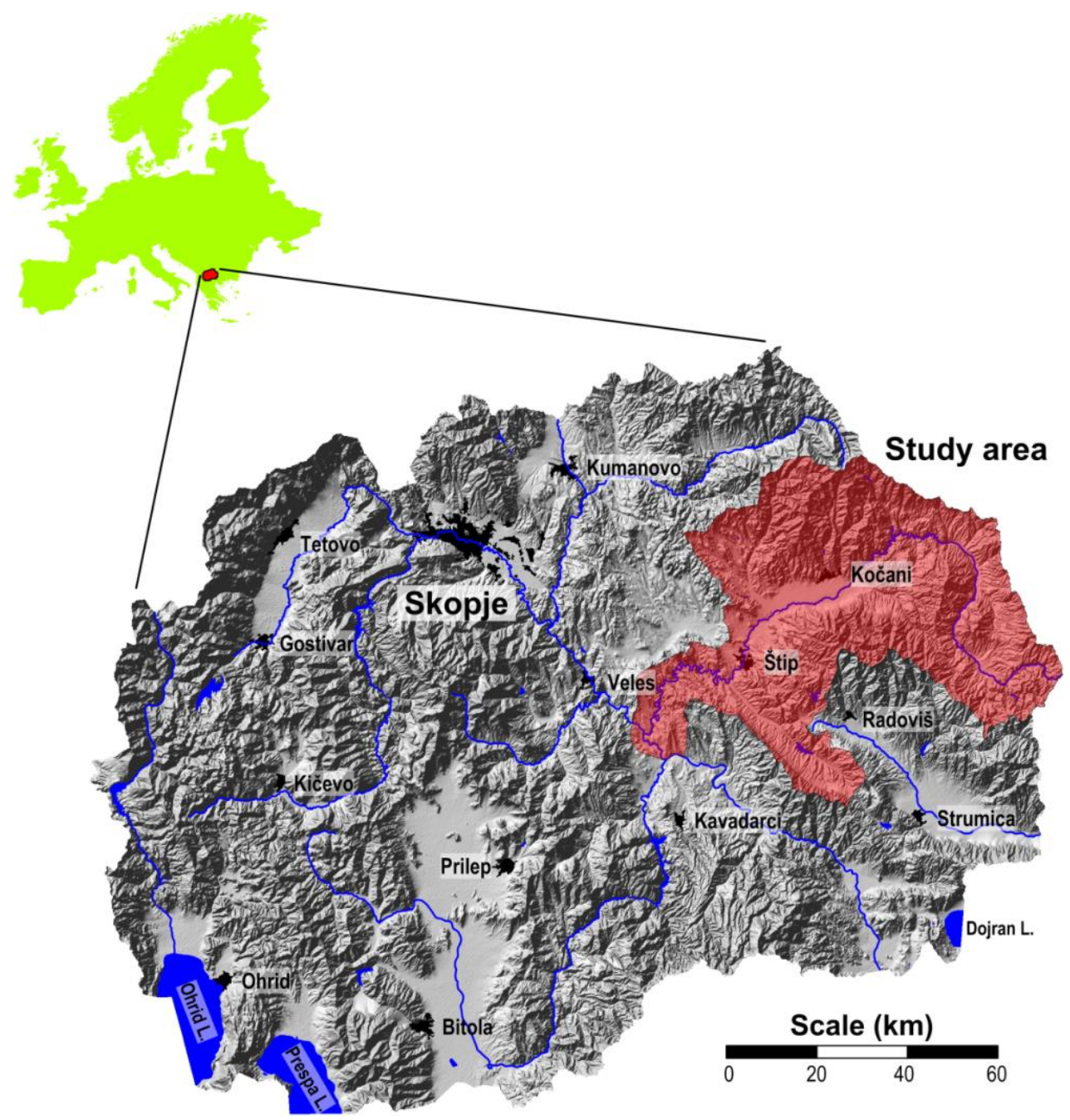

Fig. 1. The investigated area in the territory of the Republic of Macedonia

The hydrographic conditions show the influence of the formation, characteristics and geography of alluvial soils through surface flows, floods and irrigation. As a consequence of industrialization, urbanization and the lack of treatment of wastewaters from industry, mines and city sewerage, the waters of this important hydrographic catchment are exposed to a high level of pollution, in terms of the introduction of higher contents of certain toxic metals. The pollution is most fre- quently particularly high at low river flows, as in the case of the Bregalnica river in its course through the Kočani valley [24].

\subsection{Sampling}

Along the course of the Bregalnica river, in accordance with a previously specified scheme, samples of water were collected from the river plains in the period August-November 2012. Apart 
from the above-mentioned locations for sample collection along the course of the Bregalnica river, additionally some of its more important tributaries were included in order to determine the influence of the potentially polluted waters from the tributaries on the pollution of the main hydrographic factor. The more important tributaries of the Bregalnica river included in the sampling network were the following: Ratevska, Očipalska, Kamenica, Kočanska, Orizarska, Zletovska River, Lakavica and Sveti-Nikolska rivers.

The total basin area of the Bregalnica river was divided into four zones: zone 1 (Z-1) which includes 5 locations (B1, B2, B3, B4 and P1), zone
2 (Z-2), which includes the following 5 locations: B5, B6, B7, B8 and P2, zone 3 (Z-3), which includes the following 5 locations: B9, B10, B11, $\mathrm{B} 12$ and $\mathrm{B} 13$, and zone 4 (Z-4), which includes the following locations: B14, B15, B16, B17 and B18. The areas of Kamenica (K), Zletovska (Z) and Lakavica (L) rivers were separately monitored. Along the whole course of the Bregalnica river a total of 18 samples of surface water were collected according to standard procedures ISO 5667-4:1987 [25]. Additionally, surface water samples were collected from another 13 locations from the tributaries. The locations where the samples were collected are given in Figure 2.

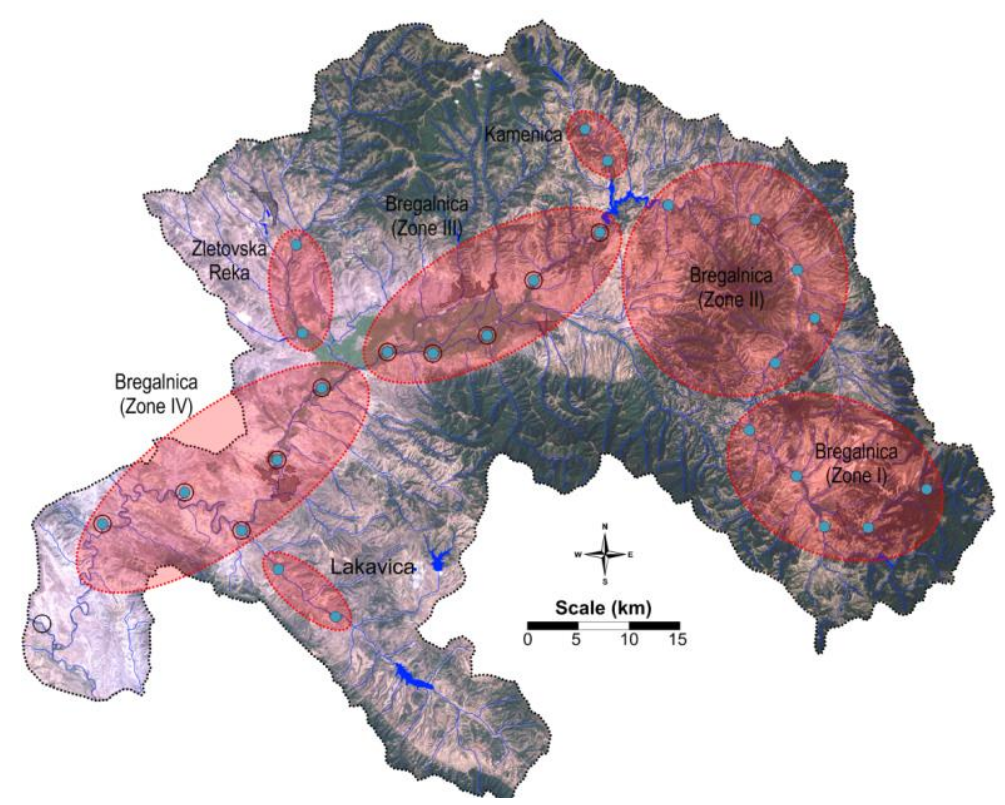

Fig. 2. Locations for taking samples of water along the course of the Bregalnica River

\subsection{Sample preparation, instrumentation and elements determination}

The surface water samples were subjected to pre-treatment included filtering through an appropriate filter and conservation with concentrated nitric acid. All the reagents and standards used have the following analytical purity level: nitric acid, $\mathrm{HNO}_{3}, 69 \%$, ultra pure (Merck, Germany). Redistilled water was used for the preparation of all solutions. The standard solutions for the elements examined were prepared by dissolution of the basic multi-element standard solution with a concentration of $1000 \mathrm{mg} \mathrm{l}^{-1}$ (11355-ICP, Multi Element Standard). Single element standard solutions were added for the elements not consisted in the multi-element standard solution. Series of standard solutions were prepared in a linear range at several concentration levels: series 1: 1, 2, 3, 5, $10 \mu \mathrm{g}^{-1}$ and series 2: $10,20,30,50,100 \mu \mathrm{g} \mathrm{l^{-1 }}$ for trace elements, series $3: 0.1 ; 0.2 ; 0.3 ; 0.5 ; 1 \mathrm{mg} \mathrm{l}^{-1}$, series 4: 1, 2, 3, 5, $10 \mathrm{mg} \mathrm{l}^{-1}$ for microelements and series 5: 10, 20, 30, 50, $100 \mathrm{mg} \mathrm{l}^{-1}$ for the elements in macro contents. Certified reference material (NIST 1643c) was used for quality control of the applied analytical methods.

A SCIEX Perkin Elmer Elan DRC II (Canada) inductively coupled plasma mass spectrometer (with quadrupole as single detector) was used for measurement of the total concentration of the trace elements. All measurements were done using the quantitative method (Total Quant) supplied by Elan 3.4 software, which uses a response factor calibration curve which was obtained by a calibration at 
multiple points, low, medium, and high concentration, for optimum setup, using a multi-element Merck VI standard solution diluted to mimic real sample consumption. The DRC was used in RFonly mode, with no collision/reaction gas.

An atomic emission spectrometer with inductively coupled plasma, ICP-AES (model
715ES, Varian, USA), was used for measurement of the concentration of several elements $(\mathrm{Al}, \mathrm{Ca}$, $\mathrm{Fe}, \mathrm{K}, \mathrm{Mg}, \mathrm{Na}$ and $\mathrm{P}$ ). For each element analyzed, prior optimization of the instrumental conditions was performed. The instrumental and operating conditions for each of the above-mentioned techniques are given in Table 1.

Table 1

Instrumental conditions for ICP-AES and ICP-MS

\begin{tabular}{|c|c|c|c|}
\hline \multicolumn{2}{|c|}{ RF generator } & ICP-AES & ICP-MS \\
\hline \multicolumn{2}{|c|}{ Power output of RF generator } & \multicolumn{2}{|c|}{$1500 \mathrm{~W}$} \\
\hline \multicolumn{2}{|c|}{ Power output stability } & \multicolumn{2}{|c|}{ Better than $0.1 \%$} \\
\hline \multicolumn{2}{|c|}{ ICP Ar flow gas rate } & \multicolumn{2}{|c|}{$151 \mathrm{~min}^{-1}$} \\
\hline \multicolumn{2}{|c|}{ Plasma parameters } & ICP-AES & ICP-MS \\
\hline \multicolumn{2}{|c|}{ Nebulizer } & V- groove & Micromist \\
\hline \multicolumn{2}{|c|}{ Spray chamber } & \multicolumn{2}{|c|}{ Double-pass cyclone } \\
\hline \multicolumn{2}{|c|}{ Peristaltic pump } & \multicolumn{2}{|c|}{$0-50 \mathrm{rpm}$} \\
\hline \multicolumn{2}{|c|}{ Cones } & 1 & Platinum \\
\hline & Radially viewed & Axially viewed \\
\hline \multicolumn{2}{|c|}{ Spectrometer } & Echelle optical design & Quadrupole \\
\hline \multicolumn{2}{|c|}{ Polychromator } & $400 \mathrm{~mm}$ focal length & 1 \\
\hline \multicolumn{2}{|c|}{ Polychromator purge } & $0.51 \mathrm{~min}^{-1}$ & 1 \\
\hline \multicolumn{2}{|c|}{ Total voltage $(\mathrm{V})$} & 1 & 0.1 \\
\hline \multicolumn{2}{|c|}{ Integration measurement time (ms) } & / & 0.1 \\
\hline \multicolumn{2}{|c|}{ Measurement at one point (isotope) (s) } & / & 300 \\
\hline \multicolumn{2}{|c|}{ Repetitions measurement } & \multicolumn{2}{|c|}{3 per point } \\
\hline \multicolumn{4}{|c|}{ Conditions for program } \\
\hline \multicolumn{2}{|c|}{ ICP-AES measurements } & \multicolumn{2}{|c|}{ ICP-MS measurements } \\
\hline Element & Wavelength, (nm) & \multirow{8}{*}{\multicolumn{2}{|c|}{$\begin{array}{c}\text { Isotopes } \\
{ }^{107} \mathrm{Ag},{ }^{75} \mathrm{As},{ }^{27} \mathrm{Al},{ }^{197} \mathrm{Au},{ }^{11} \mathrm{~B},{ }^{137} \mathrm{Ba},{ }^{9} \mathrm{Be},{ }^{209} \mathrm{Bi},{ }^{79} \mathrm{Br},{ }^{114} \mathrm{Cd}, \\
{ }^{140} \mathrm{Ce},{ }^{59} \mathrm{Co},{ }^{53} \mathrm{Cr},{ }^{133} \mathrm{Cs},{ }^{63} \mathrm{Cu},{ }^{163} \mathrm{Dy},{ }^{166} \mathrm{Er},{ }^{153} \mathrm{Eu},{ }^{56 / 57} \mathrm{Fe}, \\
{ }^{69} \mathrm{Ga},{ }^{157} \mathrm{Gd},{ }^{72} \mathrm{Ge},{ }^{178} \mathrm{Hf},{ }^{201 / 202} \mathrm{Hg},,{ }^{165} \mathrm{Ho},{ }^{127} \mathrm{I},{ }^{115} \mathrm{In},{ }^{193} \mathrm{Ir}, \\
{ }^{139} \mathrm{La},{ }^{7} \mathrm{Li},{ }^{175} \mathrm{Lu},{ }^{55} \mathrm{Mn},{ }^{95} \mathrm{Mo},{ }^{93} \mathrm{Nb},{ }^{146} \mathrm{Nd},{ }^{60} \mathrm{Ni},{ }^{189} \mathrm{Os}, \\
{ }^{206 / 207 / 208} \mathrm{~Pb},{ }^{105} \mathrm{Pd},{ }^{141} \mathrm{Pr},{ }^{195} \mathrm{Pt},{ }^{85} \mathrm{Rb},{ }^{185} \mathrm{Re},{ }^{103} \mathrm{Rh},{ }^{101} \mathrm{Ru}, \\
{ }^{121} \mathrm{Sb},{ }^{45} \mathrm{Sc},{ }^{77} \mathrm{Se},{ }^{147} \mathrm{Sm},{ }^{120} \mathrm{Sn},{ }^{88} \mathrm{Sr},{ }^{181} \mathrm{Ta},{ }^{159} \mathrm{~Tb},{ }^{125} \mathrm{Te},{ }^{47} \mathrm{Ti}, \\
{ }^{232} \mathrm{Th},{ }^{205} \mathrm{Tl},{ }^{169} \mathrm{Tm},{ }^{51} \mathrm{~V},{ }^{182} \mathrm{~W},{ }^{89} \mathrm{Y},{ }^{172} \mathrm{Yb},{ }^{66} \mathrm{Zn},{ }^{90} \mathrm{Zr}\end{array}$}} \\
\hline $\mathrm{Al}$ & 396.152 & & \\
\hline $\mathrm{Ca}$ & 370.602 & & \\
\hline $\mathrm{Fe}$ & 238.204 & & \\
\hline $\mathrm{Mg}$ & 280.270 & & \\
\hline $\mathrm{K}$ & 766.491 & & \\
\hline $\mathrm{Na}$ & 589.592 & & \\
\hline $\mathrm{P}$ & 213.618 & & \\
\hline
\end{tabular}

In all samples, the contents of a total of 69 elements were analyzed: $\mathrm{Ag}, \mathrm{As}, \mathrm{Al}, \mathrm{Au}, \mathrm{B}, \mathrm{Ba}$, $\mathrm{Be}, \mathrm{Bi}, \mathrm{Br}, \mathrm{Ca}, \mathrm{Cd}, \mathrm{Ce}, \mathrm{Co}, \mathrm{Cr}, \mathrm{Cs}, \mathrm{Cu}, \mathrm{Dy}, \mathrm{Er}, \mathrm{Eu}$, $\mathrm{Fe}, \mathrm{Ga}, \mathrm{Gd}, \mathrm{Ge}, \mathrm{Hf}, \mathrm{Hg}, \mathrm{Ho}, \mathrm{I}, \mathrm{In}, \mathrm{Ir}, \mathrm{K}, \mathrm{La}, \mathrm{Li}, \mathrm{Lu}$, $\mathrm{Mg}, \mathrm{Mn}, \mathrm{Mo}, \mathrm{Na}, \mathrm{Nb}, \mathrm{Nd}, \mathrm{Ni}$, Os, P, Pb, Pd, Pr, Pt, $\mathrm{Rb}, \mathrm{Re}, \mathrm{Rh}, \mathrm{Ru}, \mathrm{Sb}, \mathrm{Sc}, \mathrm{Se}, \mathrm{Sm}, \mathrm{Sn}, \mathrm{Sr}, \mathrm{Ta}, \mathrm{Tb}, \mathrm{Te}$, Ti, Th, Tl, Tm, V, W, Y, Yb, Zn and Zr.

The limit of detection (LOD) is usually defined as the lowest quantity or concentration of a component that can be reliably detected with a given analytical method. Intuitively, the LOD would be the lowest concentration obtained from the measurement of a sample (containing the component) that we would be able to discriminate from the concentration obtained from the measurement of a blank sample (a sample not containing the component). The calculated values for the detection limits are given in Table 2.
Table 2

Calculated instruments lower detection limits for the analyzed elements

\begin{tabular}{|c|c|}
\hline Element & $\begin{array}{c}\text { Limit of detection } \\
\mu \mathrm{g} \mathrm{l}^{-1}\end{array}$ \\
\hline $\begin{array}{c}\mathrm{Ag}, \mathrm{Au}, \mathrm{Cs}, \mathrm{Dy}, \mathrm{Eu}, \mathrm{Hf}, \mathrm{Ho}, \mathrm{In}, \mathrm{Ir} \\
\mathrm{Li}, \mathrm{Lu}, \mathrm{Os}, \mathrm{Pd}, \mathrm{Pt}, \mathrm{Re}, \mathrm{Ru}, \mathrm{Ta}, \mathrm{Tb} \\
\text { Te, Ti, Tl, Tm, W }\end{array}$ & 0.001 \\
\hline $\mathrm{Rh}$ & 0.002 \\
\hline $\begin{array}{c}\text { As, } \mathrm{Al}, \mathrm{B}, \mathrm{Ba}, \mathrm{Be}, \mathrm{Bi}, \mathrm{Br}, \mathrm{Cd}, \mathrm{Co}, \\
\mathrm{Cr}, \mathrm{Cu}, \mathrm{Eu}, \mathrm{Fe}, \mathrm{Ga}, \mathrm{Hg}, \mathrm{I}, \mathrm{K}, \mathrm{La}, \\
\mathrm{Mg}, \mathrm{Mn}, \mathrm{Mo}, \mathrm{Na}, \mathrm{Nb}, \mathrm{Nd}, \mathrm{Ni}, \mathrm{P}, \mathrm{Pr} \\
\mathrm{Rb}, \mathrm{Sb}, \mathrm{Sc}, \mathrm{Se}, \mathrm{Sm}, \mathrm{Sn}, \mathrm{Sr}, \mathrm{Th}, \mathrm{V} \\
\text { Y, Yb, Zn, Zr }\end{array}$ & 0.010 \\
\hline $\mathrm{Ce}$ & 0.050 \\
\hline $\mathrm{Pb}$ & 0.100 \\
\hline
\end{tabular}


Both certified reference materials (NIST 1643c) and spiked intra-laboratory samples were analyzed at a combined frequency of $20 \%$ of the samples.

The recovery for all of the analyzed elements ranges from $76.8 \%$ for $\mathrm{Tl}$ to $119 \%$ for $\mathrm{Sb}$ (for ICP-MS measurements) and from $87.5 \%$ for $\mathrm{Na}$ to $112 \%$ for $\mathrm{P}$ (for ICP-AES measurements).

\subsection{Data processing}

Data on the content of the investigated elements were statistically processed using statistical software (StatSoft, 11.0, Dell Software, Aliso Viejo, California, USA), by applying parametric (probability distribution, data normalization and data transformation) and non-parametric (descriptive statistics) analysis. Basic descriptive statistical analysis was conducted on the values of the contents of the elements in all types of samples. At the same time, normalization tests were done and, based on the results obtained for the certified $p$ value $>0.5$, the distribution of data on independent variables (elements' contents) was determined.

For data normalization, the Box-Cox transformation method was applied [26]. Since Box and Cox (1964), other authors have introduced modifications of this transformation for special applications and circumstances [27], but for most researchers, the original Box-Cox suffices and is preferable due to its computational simplicity. The Box-Cox transformation is given with Equations 1 and 2:

$$
\begin{array}{ll}
y=\frac{x^{\lambda}-1}{\lambda} ; & \lambda \neq 0 \\
y=\ln (\lambda) ; & \lambda=0
\end{array}
$$

where $y$ is the transformed value and $x$ is the value to be transformed. For a data set $\left(x_{1}, x_{2} \ldots x_{\mathrm{n}}\right)$, the parameter $\lambda$ is estimated based on the assumption that the transformed values $\left(y_{1}, y_{2} \ldots y_{\mathrm{n}}\right)$ are normally distributed. When $\lambda=0$, the transformation becomes the logarithmic transformation.

The level of correlation of the values of content of the chemical elements in all types of samples was estimated using bivariate statistics (using linear correlation of coefficients, $r$ ), with significance level $p<0.05 ; p<0.01$. For a clearer overview, the correlation coefficients are represented in a matrix of correlation coefficients. The application of multivariate analysis enables the number of variables to be reduced by creating new synthetic variables, again dependent on the correlation $(r)$. Factor analysis (FA) and cluster analysis (CA) were used as methods of multivariate analysis [28].

\subsection{Generalized geology and land use of the investigated area}

The investigated area that covers the basin of the Bregalnica river lies on two main tectonic units - the Serbian-Macedonian massif and the Vardar zone [29]. The polyphasal Neogene deformations through insignificant movements associated with volcanic activities had a direct influence on the gradual formation of the reefs and the formation of deposits in the existing basins (Fig. 3a). From the middle Miocene to the end of the Pleistocene, there were alternating periods of fast and slow landslides accompanied by variable sedimentation (deposition).

The Cenozoic volcanism represents a more recent extension in the Serbian-Macedonian massif and the Vardar zone. The oldest volcanic rocks occur in the areas of Bučim, Damjan, the Borov Dol district and in the zone of Toranica, Sasa, Delčevo and Pehčevo [29]. These older volcanic rocks were formed in the middle Miocene from sedimentary rocks that represent the upper age limit of the rocks. The origin of these oldest volcanic rocks is related to the Oligocene - the early Miocene period. The following rocks are categorized as volcanic: andesite, latite, quartz-latite, dacite. Volcanism appears sequentially and in several phases forming sub volcanic areas. On the other hand, the pyroclastites are most frequently found in the Kratovo-Zletovo volcanic area, where the dacites and andesites are the oldest formations. The generalized geology of the area is produced based on the data provided by Rakićević et al. [30].

Characterization of the land use of the investigated area was performed (Fig. 3b). The hydrographic conditions show an influence on the formation, characteristics and geography of soils through: surface flows, floods and irrigation. As a consequence of industrialization, urbanization and the lack of treatment of wastewaters from industry, mines and city sewerage, the waters of this important hydrographic factor are exposed to a high level of pollution, in terms of the introduction of higher contents of certain toxic metals. The pollution is most frequently particularly high at low river flows, as in the case of the Bregalnica river in its course through the Kočani valley. This whole area is intensively cultivated with crops for the irrigation of which the water from the Bregalnica river is used. The water is almost completely used for irrigation of the cultivated low terrace ( 2 to 3 m) on the right river bank [23]. 

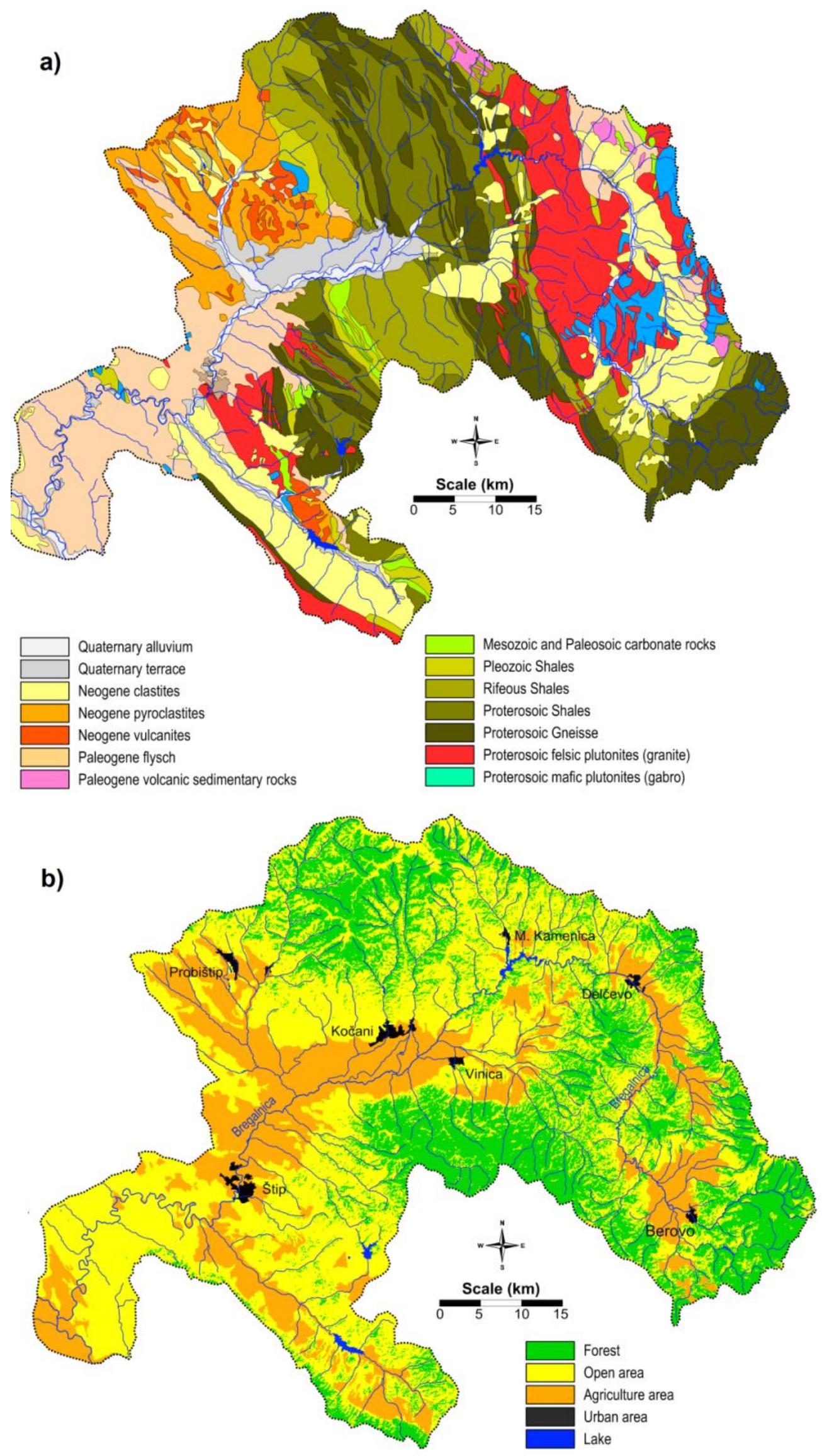

Fig. 3. Generalized geology (a) and land use (b) of the investigated area 


\section{RESULTS AND DISCUSSION}

\subsection{Elemental distribution in river water}

In all water samples a total of 69 elements were analyzed, as follows: $\mathrm{Ag}, \mathrm{As}, \mathrm{Al}, \mathrm{Au}, \mathrm{B}, \mathrm{Ba}$, $\mathrm{Be}, \mathrm{Bi}, \mathrm{Br}, \mathrm{Ca}, \mathrm{Cd}, \mathrm{Ce}, \mathrm{Co}, \mathrm{Cr}, \mathrm{Cs}, \mathrm{Cu}, \mathrm{Dy}, \mathrm{Er}, \mathrm{Eu}$, $\mathrm{Fe}, \mathrm{Ga}, \mathrm{Gd}, \mathrm{Ge}, \mathrm{Hf}, \mathrm{Hg}$, Ho, I, In, Ir, K, La, Li, Lu, $\mathrm{Mg}, \mathrm{Mn}, \mathrm{Mo}, \mathrm{Na}, \mathrm{Nb}, \mathrm{Nd}, \mathrm{Ni}, \mathrm{Os}, \mathrm{P}, \mathrm{Pb}, \mathrm{Pd}, \mathrm{Pr}, \mathrm{Pt}$, $\mathrm{Rb}, \mathrm{Re}, \mathrm{Rh}, \mathrm{Ru}, \mathrm{Sb}, \mathrm{Sc}, \mathrm{Se}, \mathrm{Sm}, \mathrm{Sn}, \mathrm{Sr}, \mathrm{Ta}, \mathrm{Tb}, \mathrm{Te}$, Ti, Th, Tl, Tm, V, W, Y, Yb, Zn and Zr. For only 14 elements were concentrations obtained that were quantified with the applied techniques in all of the analyzed water samples ( $\mathrm{Al}, \mathrm{Ca}, \mathrm{Fe}, \mathrm{K}, \mathrm{Mg}$, $\mathrm{Na}, \mathrm{P}, \mathrm{Ba}, \mathrm{Li}, \mathrm{Mn}, \mathrm{Sb}, \mathrm{Sc}, \mathrm{Sr}$, and V). The rest of the analyzed elements were determined only in samples from several locations. The concentrations of $\mathrm{Ag}, \mathrm{Bi}, \mathrm{Hg}, \mathrm{In}, \mathrm{Ga}, \mathrm{Ge}, \mathrm{Hf}, \mathrm{Ho}$, Ir, Os, Pd, Pt, $\mathrm{Rh}, \mathrm{Ru}, \mathrm{Se}, \mathrm{Ta}, \mathrm{Tb}, \mathrm{Te}, \mathrm{Th}, \mathrm{Tl}, \mathrm{Tm}$ and $\mathrm{W}$ in all of the analyzed sample locations were below the limits of detection. Table 3 shows the matrix of the concentrations ranges of the relevant elements in the samples of surface water from the whole basin area.

Table 4 presents an overview of the values of the medians of the analyzed elements, by the individual zones in the basin of the Bregalnica river. For aluminum, the highest median was obtained in the second zone $\left(1.4 \mathrm{mg} \mathrm{l}^{-1}\right)$. The concen- trations of $\mathrm{Al}$ determined in the river water along the course of the Bregalnica and its tributaries do not exceed the maximum allowed concentrations in accordance with the relevant classification for river water quality (1.5 $\left.\mathrm{mg} \mathrm{l}^{-1}\right)$ for classes II and III [31]. The medians for $\mathrm{Ca}$ in all zones range from $18 \mathrm{mg}$ $\mathrm{l}^{-1}$ in zone 1 to $61 \mathrm{mg} \mathrm{l}^{-1}$ in zone 4 . Similar distribution trends are identified in relation to the other metals, such as $\mathrm{Na}, \mathrm{Mg}, \mathrm{Li}$ and $\mathrm{Sr}$. Barium shows a continuous increase in concentration along the course of the Bregalnica river, ranging from median $2.9 \mu \mathrm{g} \mathrm{l}^{-1}$ (B1) to $51 \mu \mathrm{g} \mathrm{l^{-1 }}$ (B4). Manganese concentrations significantly differ in the upper and lower course of the river. In the upper course the medians for the two zones B1 and B3 are 0.01 and $3.2 \mu \mathrm{g}^{-1}$, respectively, while in the lower course of the river (B3 and B4), they are 190 and $180 \mu \mathrm{g}$ $1^{-1}$, respectively. Manganese may be present in water supplies as a result of natural processes involving both catchment erosion and redox-related dissolution of Mn-containing minerals at/near the sediment water interface $[32,33]$. Antimony is an element which, as concerns its concentration in the surface water, diverges from the trend of increasing concentration with increasing distance from the river source. Sb shows a decrease in concentration from the zones near the river source to the point of the flow into the river of Vardar (Table 4).

T a ble 3

Descriptive statistics for the values of the concentrations of the individual elements in water samples

\begin{tabular}{|c|c|c|c|c|c|c|c|c|c|}
\hline Element & $\mathbf{N}$ & Unit & Min & Max & Element & $\mathbf{N}$ & Unit & Min & Max \\
\hline As & 13 & $\mathrm{mg} \mathrm{l}^{-1}$ & $<\mathrm{LOD}$ & 0.019 & $\mathrm{Lu}$ & 8 & $\mu \mathrm{g} 1^{-1}$ & $<\mathrm{LOD}$ & 0.011 \\
\hline $\mathrm{Al}$ & 32 & $\operatorname{mg~} 1^{-1}$ & 0.07 & 4.1 & $\mathrm{Mg}$ & 32 & $\mathrm{mg}^{-1}$ & 3.7 & 47 \\
\hline $\mathrm{Au}$ & 3 & $\mu \mathrm{g} 1^{-1}$ & $<\mathrm{LOD}$ & 0.028 & $\mathrm{Mn}$ & 32 & $\mu \mathrm{g} 1^{-1}$ & 0.01 & 510 \\
\hline B & 17 & $\mathrm{mg} 1^{-1}$ & $<\mathrm{LOD}$ & 0.5 & Mo & 3 & $\mu \mathrm{g} 1^{-1}$ & $<\mathrm{LOD}$ & 2.9 \\
\hline $\mathrm{Ba}$ & 32 & $\mu \mathrm{g} 1^{-1}$ & 0.01 & 110 & $\mathrm{Na}$ & 32 & $\mu \mathrm{g} 1^{-1}$ & 1.9 & 86 \\
\hline $\mathrm{Be}$ & 6 & $\mu \mathrm{g} 1^{-1}$ & $<\mathrm{LOD}$ & 1.64 & $\mathrm{Nb}$ & 2 & $\mu \mathrm{g} 1^{-1}$ & $<\mathrm{LOD}$ & 1.9 \\
\hline $\mathrm{Br}$ & 4 & $\mu \mathrm{g} 1^{-1}$ & $<\mathrm{LOD}$ & 105 & $\mathrm{Nd}$ & 2 & $\mu \mathrm{g} 1^{-1}$ & $<\mathrm{LOD}$ & 2.8 \\
\hline $\mathrm{Ca}$ & 32 & $\mathrm{mg} 1^{-1}$ & 8.5 & 72 & $\mathrm{Ni}$ & 4 & $\mathrm{mg}^{-1}$ & $<\mathrm{LOD}$ & 0.0096 \\
\hline $\mathrm{Cd}$ & 8 & $\mathrm{mg} 1^{-1}$ & $<\mathrm{LOD}$ & 0.0064 & $\mathrm{P}$ & 32 & $\mathrm{mg}^{-1}$ & 0.01 & 1.1 \\
\hline Co & 4 & $\operatorname{mg~} 1^{-1}$ & $<\mathrm{LOD}$ & 0.0015 & $\mathrm{~Pb}$ & 6 & $\mathrm{mg}^{-1}$ & $<\mathrm{LOD}$ & 0.06 \\
\hline $\mathrm{Ce}$ & 6 & $\mu \mathrm{g} 1^{-1}$ & $<\mathrm{LOD}$ & 6.1 & $\mathrm{Pr}$ & 4 & $\mu \mathrm{g} 1^{-1}$ & $<\mathrm{LOD}$ & 0.078 \\
\hline $\mathrm{Cr}$ & 2 & $\mu \mathrm{g} 1^{-1}$ & $<\mathrm{LOD}$ & 11.6 & $\mathrm{Rb}$ & 14 & $\mu \mathrm{g} 1^{-1}$ & $<\mathrm{LOD}$ & 13.3 \\
\hline Cs & 4 & $\mu \mathrm{g} 1^{-1}$ & $<\mathrm{LOD}$ & 0.61 & $\mathrm{Re}$ & 2 & $\mu \mathrm{g} 1^{-1}$ & $<\mathrm{LOD}$ & 1.6 \\
\hline $\mathrm{Cu}$ & 2 & $\mathrm{mg} 1^{-1}$ & $<\mathrm{LOD}$ & 0.034 & $\mathrm{Sb}$ & 32 & $\mu \mathrm{g} 1^{-1}$ & 0.01 & 0.63 \\
\hline Dy & 2 & $\mu \mathrm{g} 1^{-1}$ & $<\mathrm{LOD}$ & 0.6 & $\mathrm{Sc}$ & 32 & $\mu \mathrm{g} 1^{-1}$ & 0.01 & 3.6 \\
\hline $\mathrm{Er}$ & 2 & $\mu \mathrm{g} 1^{-1}$ & $<\mathrm{LOD}$ & 0.3 & $\mathrm{Sm}$ & 1 & $\mu \mathrm{g} 1^{-1}$ & $<\mathrm{LOD}$ & 0.6 \\
\hline $\mathrm{Eu}$ & 2 & $\mu \mathrm{g} 1^{-1}$ & $<\mathrm{LOD}$ & 0.2 & $\mathrm{Sr}$ & 32 & $\mu \mathrm{g} 1^{-1}$ & 18 & 1400 \\
\hline $\mathrm{Fe}$ & 32 & $\mathrm{mg}^{-1}$ & 0.007 & 1.1 & $\mathrm{Ti}$ & 2 & $\mu \mathrm{g} 1^{-1}$ & $<\mathrm{LOD}$ & 984 \\
\hline $\mathrm{Gd}$ & 2 & $\mu \mathrm{g} 1^{-1}$ & $<\mathrm{LOD}$ & 0.7 & V & 32 & $\mu \mathrm{g} 1^{-1}$ & 0.01 & 21 \\
\hline I & 8 & $\mu \mathrm{g} 1^{-1}$ & $<\mathrm{LOD}$ & 2.1 & $\mathrm{Y}$ & 7 & $\mu \mathrm{g} 1^{-1}$ & $<\mathrm{LOD}$ & 2.6 \\
\hline $\mathrm{K}$ & 32 & $\operatorname{mg~} 1^{-1}$ & 0.67 & 11 & $\mathrm{Yb}$ & 1 & $\mu \mathrm{g} 1^{-1}$ & $<\mathrm{LOD}$ & 0.3 \\
\hline $\mathrm{La}$ & 2 & $\mu \mathrm{g} 1^{-1}$ & $<\mathrm{LOD}$ & 2.7 & $\mathrm{Zn}$ & 5 & $\mu \mathrm{g} 1^{-1}$ & $<\mathrm{LOD}$ & 1099 \\
\hline $\mathrm{Li}$ & 32 & $\mu \mathrm{g} 1^{-1}$ & 0.52 & 49 & $\mathrm{Zr}$ & 2 & $\mu \mathrm{g} 1^{-1}$ & $<\mathrm{LOD}$ & 5.3 \\
\hline
\end{tabular}

Min - minimum; Max - maximum; LOD - instrument limit of detection; $\mathrm{N}$ - number of sample locations with the element concentration above LOD 
Table 4

Mean values of the analyzed elements in 4 zones along the course of the Bregalnica river and its tributaries

\begin{tabular}{|c|c|c|c|c|c|c|c|c|}
\hline Element & Unit & Z1 & $\mathbf{Z 2}$ & $\mathbf{Z 3}$ & 24 & $\bar{K}$ & $\mathbf{Z}$ & $\mathbf{L}$ \\
\hline Al & $\mathrm{mg} \mathrm{l}^{-1}$ & 0.26 & 1.4 & 0.20 & 0.42 & 0.83 & 0.32 & 0.076 \\
\hline $\mathrm{Ca}$ & $\mathrm{mg}^{-1}$ & 18 & 33 & 43 & 61 & 31 & 28 & 66 \\
\hline $\mathbf{F e}$ & $\mathrm{mg} \mathrm{l}^{-1}$ & 0.081 & 0.19 & 0.41 & 0.25 & 0.08 & 0.059 & 0.034 \\
\hline $\mathbf{K}$ & $\mathrm{mg} \mathrm{l}^{-1}$ & 2.4 & 2.6 & 4.4 & 5.7 & 1.5 & 2.5 & 2.6 \\
\hline Mg & $\mathrm{mg} \mathrm{l}^{-1}$ & 5.4 & 10 & 12 & 17 & 4.6 & 6.1 & 15 \\
\hline $\mathrm{Na}$ & $\mu \mathrm{g}^{-1}$ & 4.4 & 7.6 & 19 & 21 & 2.1 & 4.1 & 10 \\
\hline $\mathbf{P}$ & $\mathrm{mg} \mathrm{l}^{-1}$ & 0.018 & 0.026 & 0.049 & 0.11 & 0.01 & 0.01 & 0.01 \\
\hline $\mathbf{B a}$ & $\mu \mathrm{g}^{-1}$ & 2.9 & 19 & 37 & 51 & 5.4 & 25 & 72 \\
\hline $\mathbf{L i}$ & $\mu \mathrm{g}^{-1}$ & 0.89 & 1.8 & 9.9 & 9.7 & 0.99 & 1.4 & 4.2 \\
\hline Mn & $\mu \mathrm{g} \mathrm{l}^{-1}$ & 0.01 & 3.2 & 190 & 180 & 380 & 6.3 & 96 \\
\hline $\mathbf{S b}$ & $\mu \mathrm{g} \mathrm{l}^{-1}$ & 0.10 & 0.087 & 0.062 & 0.01 & 0.43 & 0.23 & 0.24 \\
\hline Sc & $\mu \mathrm{g}^{-1}$ & 0.92 & 0.84 & 0.93 & 1.9 & 0.43 & 0.53 & 2.3 \\
\hline $\mathrm{Sr}$ & $\mu \mathrm{g} \mathrm{l}^{-1}$ & 46 & 98 & 190 & 360 & 110 & 180 & 320 \\
\hline $\mathbf{V}$ & $\mu \mathrm{g} \mathrm{l}^{-1}$ & 0.25 & 1.3 & 0.37 & 1.4 & 0.13 & 0.029 & 13 \\
\hline As & $\mu \mathrm{g}^{-1}$ & n.d. & 0.13 & 1.65 & 1.08 & 0.77 & n.d. & 4.0 \\
\hline Au & $\mu \mathrm{g}^{-1}$ & n.d. & n.d. & n.d. & n.d. & 0.02 & n.d. & n.d. \\
\hline B & $\mu \mathrm{g} \mathrm{l}^{-1}$ & n.d. & n.d. & 92.7 & 88.5 & n.d. & n.d. & 41.0 \\
\hline $\mathrm{Be}$ & $\mu \mathrm{g}^{-1}$ & n.d. & n.d. & 0.13 & 0.13 & 0.55 & n.d. & 0.12 \\
\hline $\mathbf{B r}$ & $\mu \mathrm{g} \mathrm{l}^{-1}$ & n.d. & n.d. & n.d. & n.d. & n.d. & n.d. & 74.3 \\
\hline Cd & $\mu \mathrm{g} \mathrm{l}^{-1}$ & n.d. & n.d. & n.d. & n.d. & 4.8 & n.d. & 0.07 \\
\hline Co & $\mu \mathrm{g}^{-1}$ & n.d. & n.d. & n.d. & n.d. & 0.49 & n.d. & 2.1 \\
\hline $\mathrm{Ce}$ & $\mu \mathrm{g}^{-1}$ & n.d. & 0.24 & 0.11 & n.d. & 0.12 & n.d. & 3.2 \\
\hline $\mathrm{Cr}$ & $\mu \mathrm{g} \mathrm{l}^{-1}$ & n.d. & n.d. & n.d. & n.d. & n.d. & n.d. & 6.0 \\
\hline Cs & $\mu \mathrm{g}^{-1}$ & n.d. & n.d. & 0.24 & n.d. & n.d. & n.d. & 0.29 \\
\hline $\mathrm{Cu}$ & $\mu \mathrm{g} \mathrm{l}^{-1}$ & n.d. & n.d. & n.d. & n.d. & n.d. & n.d. & 31.1 \\
\hline Dy & $\mu \mathrm{g} \mathrm{l}^{-1}$ & n.d. & n.d. & n.d. & n.d. & n.d. & n.d. & 0.3 \\
\hline $\mathbf{E r}$ & $\mu \mathrm{g}^{-1}$ & n.d. & n.d. & n.d. & n.d. & n.d. & n.d. & 0.16 \\
\hline $\mathbf{E u}$ & $\mu \mathrm{g} \mathrm{l}^{-1}$ & n.d. & n.d. & n.d. & n.d. & n.d. & n.d. & 0.076 \\
\hline Gd & $\mu \mathrm{g} \mathrm{l}^{-1}$ & n.d. & n.d. & n.d. & n.d. & n.d. & n.d. & 0.40 \\
\hline I & $\mu \mathrm{g}^{-1}$ & n.d. & n.d. & n.d. & 0.27 & n.d. & n.d. & 1.2 \\
\hline La & $\mu \mathrm{g} \mathrm{l}^{-1}$ & n.d. & n.d. & n.d. & n.d. & n.d. & n.d. & 1.4 \\
\hline Lu & $\mu \mathrm{g} \mathrm{l}^{-1}$ & n.d. & n.d. & n.d. & n.d. & 0.005 & n.d. & n.d. \\
\hline Mo & $\mu \mathrm{g}^{-1}$ & n.d. & n.d. & n.d. & n.d. & n.d. & n.d. & 2.9 \\
\hline $\mathbf{N b}$ & $\mu \mathrm{g} \mathrm{l}^{-1}$ & n.d. & n.d. & n.d. & n.d. & n.d. & n.d. & 1.9 \\
\hline Nd & $\mu \mathrm{g}^{-1}$ & n.d. & n.d. & n.d. & n.d. & n.d. & n.d. & 1.5 \\
\hline $\mathbf{N i}$ & $\mu \mathrm{g}^{-1}$ & n.d. & n.d. & n.d. & n.d. & 0.9 & 50.8 & 5.3 \\
\hline $\mathbf{P b}$ & $\mu \mathrm{g} \mathrm{l}^{-1}$ & n.d. & n.d. & n.d. & 0.60 & 21.3 & n.d. & 7.6 \\
\hline Pr & $\mu \mathrm{g}^{-1}$ & n.d. & 0.02 & 0.03 & n.d. & 0.04 & n.d. & n.d. \\
\hline $\mathbf{R e}$ & $\mu \mathrm{g}^{-1}$ & n.d. & n.d. & n.d. & n.d. & n.d. & n.d. & 1.5 \\
\hline $\mathbf{R b}$ & $\mu \mathrm{g} \mathrm{l}^{-1}$ & n.d. & n.d. & 2.51 & 1.48 & 0.9 & n.d. & 7.2 \\
\hline Sm & $\mu \mathrm{g}^{-1}$ & n.d. & n.d. & n.d. & n.d. & n.d. & n.d. & 0.6 \\
\hline $\mathbf{T i}$ & $\mu \mathrm{g} \mathrm{l}^{-1}$ & n.d. & n.d. & n.d. & n.d. & n.d. & n.d. & 587 \\
\hline $\mathbf{Y}$ & $\mu \mathrm{g} \mathrm{l}^{-1}$ & n.d. & 0.37 & n.d. & 0.17 & 0.18 & n.d. & 1.52 \\
\hline $\mathbf{Y b}$ & $\mu \mathrm{g}^{-1}$ & n.d. & n.d. & n.d. & n.d. & n.d. & n.d. & 0.3 \\
\hline $\mathbf{Z n}$ & $\mu \mathrm{g} \mathrm{l}^{-1}$ & n.d. & n.d. & n.d. & n.d. & 664 & n.d. & 19.8 \\
\hline $\mathbf{Z r}$ & $\mu \mathrm{g}^{-1}$ & n.d. & n.d. & n.d. & n.d. & n.d. & n.d. & 2.7 \\
\hline Tot. conc. & $\mathrm{mg}^{-1}$ & 12.8 & 25.2 & 226 & 225 & 389 & 19.7 & 125 \\
\hline
\end{tabular}

$\mathrm{Z} 1$ - zone 1; Z2 - zone 2; Z3 - zone 3; Z4 - zone 4; $\mathrm{N}$ - number of samples in each zone; $\mathrm{K}$ - the Kamenica river course; $\mathrm{Z}$ - the Zletovska Reka river course ; $\mathrm{L}$ - the Lakavica river course;

Tot. conc. - total concentration of elements determined above LOD; n.d. - not detected

The concentrations of $\mathrm{Sb}$ determined in the river water along the course of the Bregalnica river and its tributaries do not exceed the maximum allowed concentrations in accordance with the relevant classification for river water quality, 30 $\mu \mathrm{g} 1^{-1}$, for classes II and III [31]. Scandium concentrations did not show any significant variability among the zones along the Bregalnica river basin, 
nor along the more important tributaries. The medians for the four zones are 0.92, 0.84, 0.93, and $1.9 \mu \mathrm{g} \mathrm{l}^{-1}$, respectively. It is worth mentioning that scandium has been considered as a rare earth element, naturally occurring most frequently in areas with uranium ore deposits. Nevertheless, in the last decades it has been established that this element can very frequently be found in areas naturally enriched with $\mathrm{Al}$ and $\mathrm{Fe}$. Vanadium concentrations in surface waters in the Bregalnica river basin are in the range from 0.010 to $21 \mu \mathrm{g} \mathrm{l}^{-1}$, and do not exceed the maximum allowed concentrations in accordance with the relevant classification for river water quality, $100 \mu \mathrm{g} \mathrm{l^{-1 }}$ for class II and $200 \mu \mathrm{g} \mathrm{l^{-1 }}$ for class III [31].

In addition to the above-mentioned elements, Table 4 also presents concentrations of certain elements which were determined only for certain areas (by zones) in the Bregalnica river basin. Arsenic concentrations (Table 4) do not exceed the maximum allowed concentrations in accordance with the relevant classification (class) for river water quality, $30 \mu \mathrm{g}^{-1}$ for class II and 50 $\mu \mathrm{g}^{-1}$ for class III [31]. The cadmium concentration obtained from the surface water of the $\mathrm{Ka}$ menica river $\left(4.8 \mu \mathrm{g}^{-1}\right)$ does not exceed the maximum allowed concentrations in accordance with the relevant classification (class) for river water quality, $10 \mu \mathrm{g}^{-1}$ for class III [31]. The copper concentration was determined only in the water of the Lakavica river $\left(31 \mu \mathrm{g}^{-1}\right)$, and does not exceed the maximum allowed concentration in accordance with the relevant classification (class) for river water quality, $50 \mu \mathrm{g}^{-1}$ for class III [31]. Nickel concentrations were determined in the waters of the Kamenica, Zletovska and Lakavica rivers (0.9; 50.8 and $5.3 \mu \mathrm{g}^{-1}$, respectively, presented in Table 4). In the Kamenica river, the average value of $\mathrm{Pb}$ concentration amounts to $21.3 \mu \mathrm{g} \mathrm{1^{-1 }}$, and it does not exceed the maximum allowed concentration in accordance with the relevant classification (class) for river water quality, $30 \mu \mathrm{g} \mathrm{l}^{-1}$ for class III [31]. It was determined that only in the waters of the Kamenica river did the $\mathrm{Zn}$ concentration (average $664 \mu \mathrm{g} \mathrm{l}^{-1}$ ) exceed the maximum allowed concentration in accordance with the relevant classification for river water quality, $200 \mu \mathrm{g}^{-1}$ for class III [31]. Furthermore, agricultural burning or Znbased fungicides can be an additional source of zinc $[34,35]$

\subsection{Multivariate assessment for elements distribution}

In order to give a better picture of the interdependence of the analyzed elements, multivariate factor analysis was conducted. This statistical method was applied for the elements that were determined to be above the instrumental LOD in all zones in the investigated area $(\mathrm{Al}, \mathrm{Ca}, \mathrm{Fe}, \mathrm{K}$, $\mathrm{Mg}, \mathrm{Na}, \mathrm{P}, \mathrm{Ba}, \mathrm{Li}, \mathrm{Mn}, \mathrm{Sb}, \mathrm{Sc}, \mathrm{Sr}$ and V). Based on the constructed matrix of correlation coefficients (given in Table 5), statistical screening for Eigen-values (E-values) was performed in order to single out only the significant synthetic variables $(\mathrm{E}>1)$. The values for the isolated factors loadings $(\mathrm{F} 1, \mathrm{~F} 2, \mathrm{~F} 3)$ are presented in Table 6.

Table 5

Correlation matrix of dominant elements (bold values significant at $p>0.05$ )

\begin{tabular}{|c|c|c|c|c|c|c|c|c|c|c|c|c|c|c|}
\hline $\mathrm{Al}$ & 1.00 & & & & & & & & & & & & & \\
\hline $\mathrm{Ca}$ & -0.35 & 1.00 & & & & & & & & & & & & \\
\hline $\mathrm{Fe}$ & 0.43 & 0.00 & 1.00 & & & & & & & & & & & \\
\hline K & 0.00 & 0.55 & 0.43 & 1.00 & & & & & & & & & & \\
\hline $\mathrm{Mg}$ & -0.31 & 0.90 & 0.03 & 0.69 & 1.00 & & & & & & & & & \\
\hline $\mathrm{Na}$ & -0.23 & 0.80 & 0.25 & 0.83 & 0.91 & 1.00 & & & & & & & & \\
\hline $\mathrm{P}$ & 0.12 & 0.36 & 0.52 & 0.80 & 0.54 & 0.70 & 1.00 & & & & & & & \\
\hline $\mathrm{Ba}$ & -0.20 & 0.78 & 0.11 & 0.62 & 0.76 & 0.74 & 0.46 & 1.00 & & & & & & \\
\hline $\mathrm{Li}$ & -0.20 & 0.80 & 0.36 & 0.76 & 0.84 & 0.87 & 0.68 & 0.80 & 1.00 & & & & & \\
\hline $\mathrm{Mn}$ & 0.15 & 0.62 & 0.50 & 0.37 & 0.37 & 0.41 & 0.26 & 0.50 & 0.61 & 1.00 & & & & \\
\hline $\mathrm{Sb}$ & 0.04 & -0.15 & -0.22 & -0.22 & -0.30 & -0.28 & -0.34 & -0.13 & -0.27 & 0.09 & 1.00 & & & \\
\hline Sc & -0.30 & $\mathbf{0 . 5 6}$ & 0.28 & 0.35 & 0.54 & 0.56 & 0.37 & 0.40 & 0.54 & 0.41 & -0.26 & 1.00 & & \\
\hline $\mathrm{Sr}$ & -0.21 & 0.86 & 0.11 & 0.67 & 0.81 & 0.73 & 0.44 & 0.79 & 0.84 & 0.65 & 0.02 & 0.37 & 1.00 & \\
\hline V & -0.05 & 0.70 & 0.05 & 0.37 & 0.70 & 0.58 & 0.24 & 0.61 & 0.58 & 0.40 & -0.30 & 0.59 & 0.52 & 1.00 \\
\hline & $\mathrm{Al}$ & $\mathrm{Ca}$ & $\mathrm{Fe}$ & $\mathrm{K}$ & $\mathrm{Mg}$ & $\mathrm{Na}$ & $P$ & $\mathrm{Ba}$ & $\mathrm{Li}$ & $\mathrm{Mn}$ & $\mathrm{Sb}$ & $\mathrm{Sc}$ & $\mathrm{Sr}$ & $\mathrm{V}$ \\
\hline
\end{tabular}


Based on the multivariate processing of the values for the analyzed elements' content, three dominant factors were singled out: factor $1(\mathrm{~F} 1)$, with a dominant loading value of 6.65 and variability $58.7 \%$ of the total variability $(80.6 \%)$. This factor associates the following elements: $\mathrm{Ca}-\mathrm{K}-$ Mg-Na-Ba-Li-Mn-Sr-V (Table 6). The highest loading value in this geochemical association of elements was obtained for calcium (0.94). The second factor associates the elements Al-Fe, with variability of $15 \%$ and $E$-value $=1.78$ (Table 6). The third and least distinguished factor is represented by antimony, which covers $10.7 \%$ of the total variability of the factor loadings matrix, and has the lowest E-value.

\section{Table 6}

\section{Matrix of factor loadings - factor analysis (FA) of elements' concentration in surface}

\begin{tabular}{ccccc}
\hline \hline Element & F1 & F2 & F3 & Comm \\
\hline Ca & $\mathbf{0 . 9 4}$ & -0.16 & 0.06 & 91.8 \\
K & $\mathbf{0 . 7 4}$ & 0.31 & -0.23 & 70.2 \\
Mg & $\mathbf{0 . 9 3}$ & -0.16 & -0.22 & 93.4 \\
Na & $\mathbf{0 . 9 0}$ & 0.04 & -0.25 & 86.9 \\
Ba & $\mathbf{0 . 8 8}$ & -0.02 & 0.03 & 76.9 \\
Li & $\mathbf{0 . 9 3}$ & 0.17 & -0.12 & 90.0 \\
Mn & $\mathbf{0 . 6 3}$ & 0.49 & 0.41 & 80.5 \\
Sr & $\mathbf{0 . 9 2}$ & 0.01 & 0.23 & 89.7 \\
V & $\mathbf{0 . 7 0}$ & -0.04 & -0.18 & 52.3 \\
Al & -0.27 & $\mathbf{0 . 7 6}$ & 0.05 & 65.7 \\
Fe & 0.17 & $\mathbf{0 . 8 9}$ & -0.15 & 84.8 \\
Sb & -0.17 & -0.08 & $\mathbf{0 . 9 0}$ & 85.2 \\
\hline Variability (\%) & 58.7 & 15.1 & 10.7 & $\mathbf{8 0 . 6}$ \\
Eingene value & 6.65 & 1.78 & 1.24 & \\
\hline \hline
\end{tabular}

F1 - values of Factor 1 loadings; F2 - values of Factor 2 loadings; F3 - values of Factor 3 loadings; Comm - communality (\%)

The values for the concentration of the elements in the surface water were placed in a functional dependence of two variables. Graphical representations are provided for the distribution of the concentrations of each element depending on the distance from the source of the Bregalnica river to its flow into the river of Vardar, including all its tributaries (Figs. 4-7). For a better visual presentation, the factor standard values for $\mathrm{F} 1$ ( $\mathrm{Ca}-\mathrm{K}-\mathrm{Mg}$ $\mathrm{Na}-\mathrm{Ba}-\mathrm{Li}-\mathrm{Mn}-\mathrm{Sr}-\mathrm{V})$ are presented in Figures 4 and $5 \mathrm{a}$, for $\mathrm{F} 2(\mathrm{Al}-\mathrm{Fe})$ in Figures $5 \mathrm{~b}$ and 6 , and for F3 $(\mathrm{Sb})$ in Figures $5 \mathrm{c}$ and 7.

Factor 1 (Ca-K-Mg-Na-Ba-Li-Mn-Sr-V) presents a dominant geochemical marker for the Bre- galnica river basin. The distribution of the first and dominant geochemical association, as can be seen from the graphical representation, shows no significant deviation in the concentrations of these elements along the whole course of the Bregalnica river (Fig. 4). This is probably due to the thickening of the organic mass that reaches the river water, either naturally or anthropogenic reasons. Furthermore, the lithological distribution of these elements relies on very specific geology, namely, the dominant geological formations in the four zones: Neogene clastites (Zone I), Proterozoic granite (Zone II), Proterozoic gneisses and shales and Quaternary alluvium (Zone III) and Paleogene flysch in Zone IV. The concentrations of these elements in the tributaries behave in a very similar way, with the highest concentration of these elements (standard value 0.7) in the Kamenica river (Fig. 5a). The $\mathrm{Pb}-\mathrm{Zn}$ mineralization that occurs in this area is based on the dominant Proterozoic gneisses and Paleogene volcanic sedimentary rocks. Very similar results were obtained for enrichments of these element associations in previous investigations [17], so this appearance probably represents a natural phenomenon.

The second geochemical association of the elements Al-Fe shows a specific trend of distribution of these elements in the waters of the Bregalnica river basin (Fig. 6). Higher concentrations are specific to Zone IV, including the area where the Lakavica river flows into Bregalnica. The Lacavica river is dominant among the tributaries by the natural enrichment of water with this geochemical factor (Fig. 5b). This tributary is located across the Bučim-Damjan-Borov Dol ore district, where the Bučim copper mine and former Damjan Fe mine are located. The appearances of some elements are related to the specific $\mathrm{Cu}-\mathrm{Au}$ mineralization as dominant, but enrichment in light rare earth elements (LREE) and relatively flat heavy REE (HREE) patterns is also a general feature of the Bučim region [36-38]. Large ion lithophile elements (LILE) such as $\mathrm{U}, \mathrm{Th}, \mathrm{Pb}$ are enriched; the high field strength elements (HFSE) like $\mathrm{Zr}, \mathrm{Hf}, \mathrm{Nb}$ and $\mathrm{Ta}$ display negative anomalies according to Lehmann et al. [37]. Exclusively, the Lakavica river, unlike all the other tributaries, only contains significant concentrations of certain elements $(\mathrm{Br}-\mathrm{Ce}-\mathrm{Cu}-$ Cr-Cs-Dy-Er-Eu-Gd-I-La-Mo-Nd-Nb-Re-Sm-Tl-W$\mathrm{Y}-\mathrm{Zr}$ ) and thus introduces them in the lower path (Zone IV, Fig. 2). Since these elements are at very low concentrations $\left(\mu \mathrm{g} \mathrm{l}^{-1}\right)$ in the samples from the rest of the locations (below instrumental LOD), the $\mathrm{Al}-\mathrm{Fe}$ geochemical association appears as their marker. 


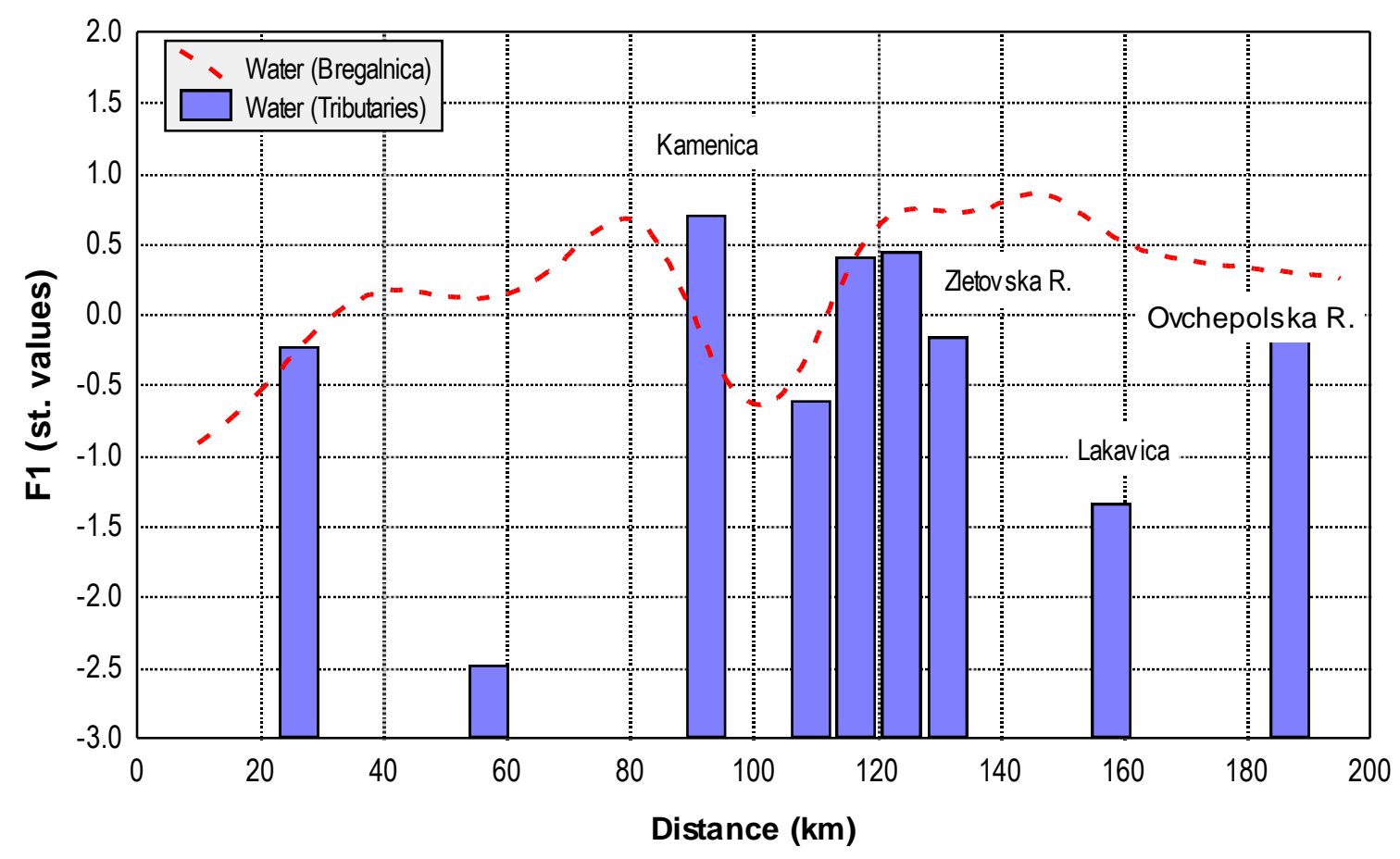

Fig. 4. Distribution of F1 elements along the course of Bregalnica and its tributaries, depending on the distance from the river source

(Tributary rivers: Ratevska, Ocepalska, Kamenica, Osojnica, Orizarska, Kočanska, Zletovska, Lakavica, Ovčepolska)

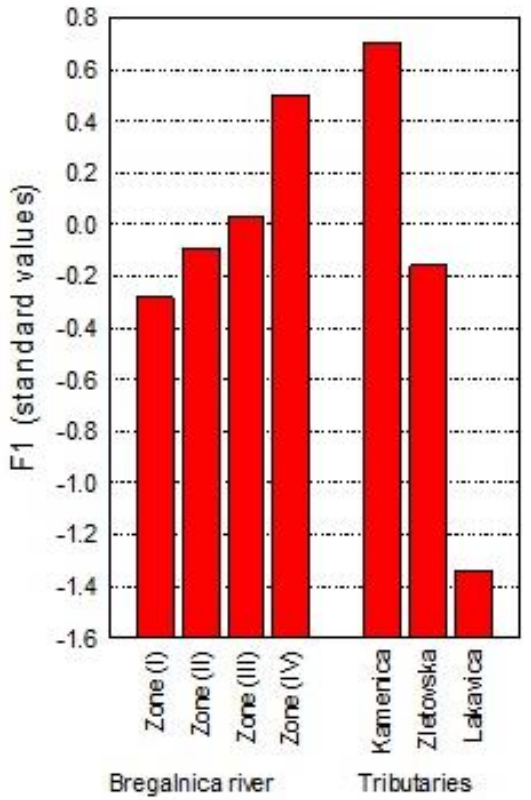

a)

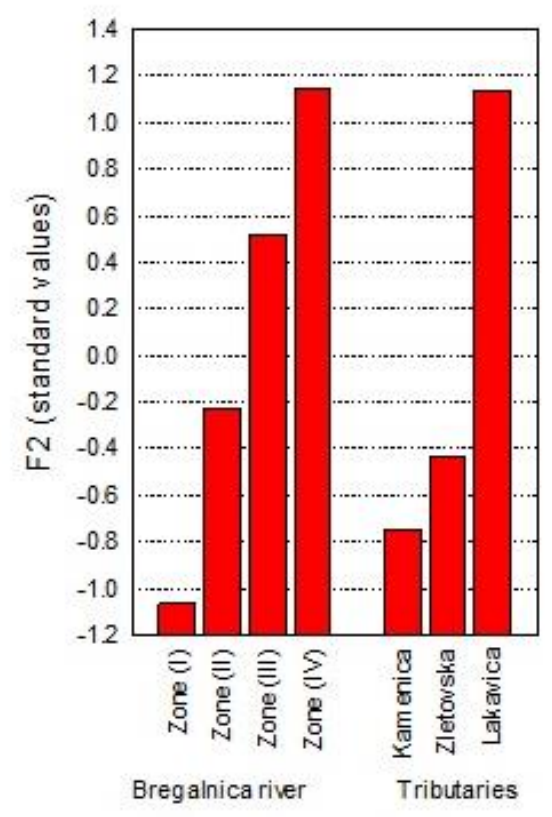

b)

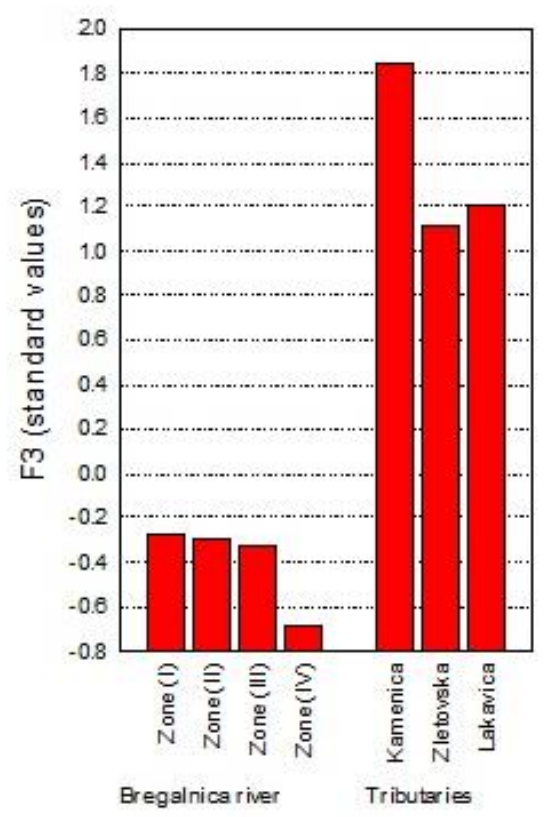

c)

Fig. 5. Distribution of geochemical association F1 (a), F2 (b) and F3 (c) across the Bregalnica river zones and main tributaries 


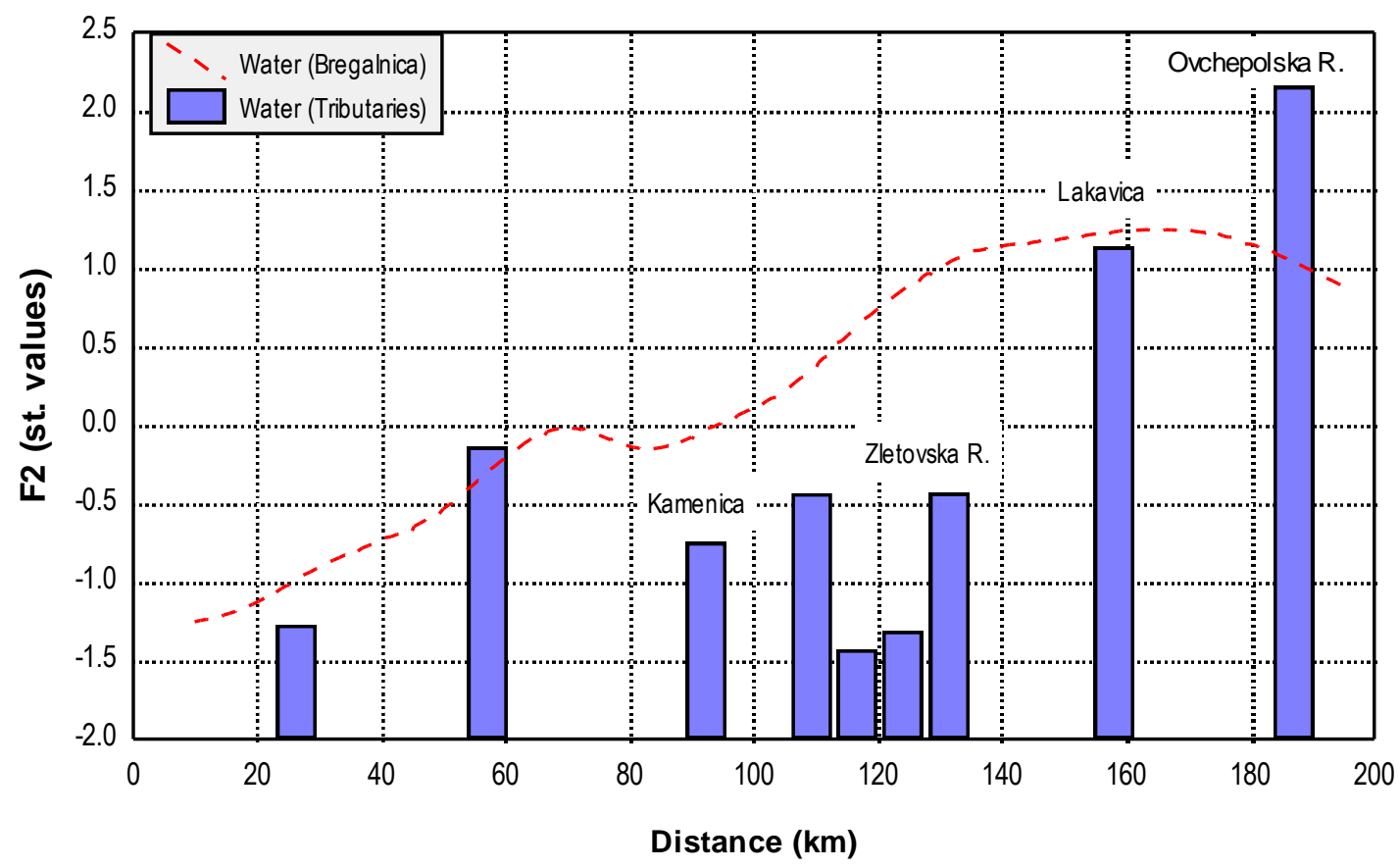

Fig. 6. Distribution of F2 elements along the course of Bregalnica and its tributaries, depending on the distance from the river source

(Tributary rivers: Ratevska, Očepalska, Kamenica, Osojnica, Orizarska, Kočanska, Zletovska, Lakavica, Ovčepolska)

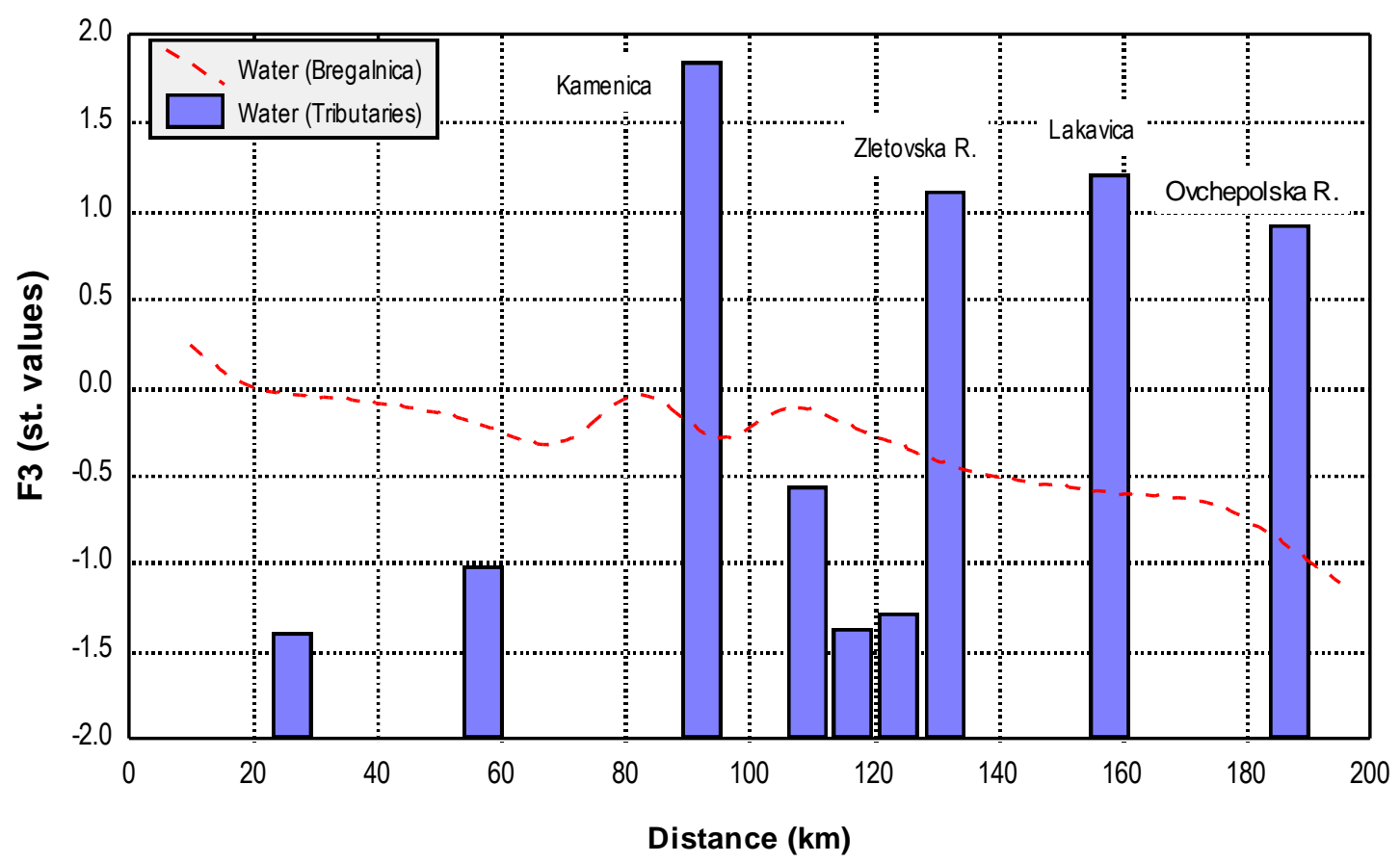

Fig. 7. Distribution of F3 elements along the course of Bregalnica and its tributaries, depending on the distance from the river source

(Tributaries: Ratevska, Očepalska, Kamenica, Osojnica, Orizarska, Kočanska, Zletovska, Lakavica, Ovčepolska)

The distribution of the third factor is represented by the dominance and high loading value for antimony. Along the course of the Bregalnica river a mild decreasing trend in the concentration of this element is observed with the increase in distance from the river source (Fig. 7). Higher standard values were obtained for this geochemical factor in four tributaries: Kamenica, Zletovska, Lakavica and Ovčepolska rivers. The average value calculated for the concentration of $\mathrm{Sb}$ in surface water from Kamenica is $0.43 \mu \mathrm{g} \mathrm{l}^{-1}$, but significant concentrations were obtained also for other ele- 
ments: As $\left(0.77 \mu \mathrm{g} \mathrm{1^{-1 }}\right), \mathrm{Au}\left(0.02 \mu \mathrm{g}^{-1}\right), \mathrm{Be}(0.55$ $\left.\mu \mathrm{g}^{-1}\right)$, Cd $\left(4.8 \mu \mathrm{g}^{-1}\right)$, Co $\left(0.49 \mu \mathrm{g}^{-1}\right)$, Ce $(0.12$ $\left.\mu \mathrm{g} 1^{-1}\right), \mathrm{Ni}\left(0.9 \mu \mathrm{g} 1^{-1}\right), \mathrm{Pb}\left(21.3 \mu \mathrm{g} \mathrm{1^{-1 }}\right)$ and $\mathrm{Zn}(664$ $\mu \mathrm{g}^{-1}$ ). The Kamenica river flows across the specific old geological formation with $\mathrm{Pb}-\mathrm{Zn}$ mineralization (Paleogene volcanic sedimentary rocks and Proterozoic gneisses and shales). On the other hand, the area with older volcanism occurs in the basin of Zletovska river, with a dominant presence of Neogene vulcanites, clastites and pyroclastites [23]. Water from Zletovska river contains an average concentration of antimony of $0.23 \mu \mathrm{g} \mathrm{l}^{-1}$ (Table 4). Despite the antimony, the water from Zletovska river is characterized also by a significant concentration of $\mathrm{Ni}\left(50.8 \mu \mathrm{g} \mathrm{l}^{-1}\right)$. The occurrence of F3 $\mathrm{Sb}$ ) in the Lakavica river tributary, with a standard value of 1.23 , is calculated as having an average concentration of $0.24 \mu \mathrm{g} \mathrm{l}^{-1}$, while in Ovčepolska River the antimony concentration is $0.41 \mu \mathrm{g} \mathrm{l}^{-1}$. The occurrence of this factor is related with two dominant metallic mineralizations in the sampling area, $\mathrm{Pb}-\mathrm{Zn}$ mineralization in the locality of $\mathrm{Ka}-$ menica and Zletovska rivers, and $\mathrm{Cu}-\mathrm{Au}$ mineralization among the flows of Lakavica river. The graphical bar chart (Fig. 5c) presents the significantly higher standard values for these tributaries compared with the other zones.

\subsection{Spatial distribution of dominant elements pattern}

Visualizations of the areal distribution of these three dominant lithological markers are given in Fig. 8. The basic introduction of the lithogenic markers and their distribution along the Bregalnica river is due to their occurrence in the four significant tributaries: Kamenica, Zletovska, Lakavica and Ovčepolska rivers. Apart from the specific metallic mineralization, the enrichments of these elements are significantly influenced by the anthropogenic agro-technical processes in the basin of Ovčepolska river. According to the land use map (Fig. 2), the Kamenica river area is a dominant open area, and the rest of the basin of Bregalnica is intensively used for agriculture. Very similar introductions of certain elements occur in Zone 3 (Kočani valley) and Zone 4.

The effect of the Kamenica river is alleviated by the presence of the hydro accumulation at Kalimanci, which acts as an accumulator of higher concentrations and deposits of flotation tailings from the "Sasa" mine. The dominance of the third factor $(\mathrm{Sb})$ is related with the occurrence of the $\mathrm{Pb}$ and $\mathrm{Zn}$ in water. As well as lead and zinc, in this tributary As and Cd were also determined (average concentrations 0.77 and $4.8 \mu \mathrm{g} \mathrm{l}^{-1}$ ). The total elements concentration is $389 \mathrm{mg} \mathrm{l}^{-1}$.

Very similar behavior to that of the Kamenica river is shown by the Lakavica river, where the total elements concentration is $125 \mathrm{mg} \mathrm{l}^{-1}$ (as given in Table 4). The anthropogenic introduction of $\mathrm{Cu}\left(31 \mu \mathrm{g} \mathrm{l}^{-1}\right)$ is due to the continuous outpouring of waste waters from the ore and flotation plant at the "Bučim" copper mine. The Fe mineralization and the presence of the former "Damjan" Fe mine have similar effects, so the dominant factor is the second factor (Al-Fe).
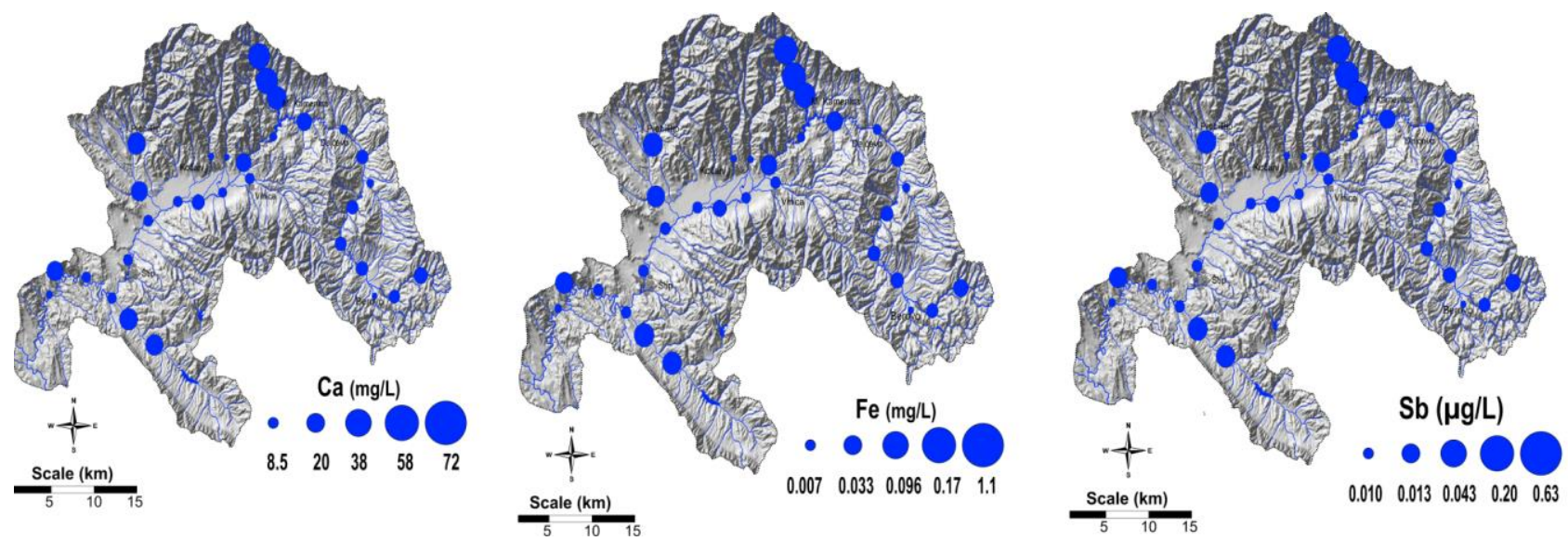

Fig. 8. Spatial distribution of $\mathrm{Ca}, \mathrm{Fe}$ and $\mathrm{Sb}$ in the surface river waters in the Bregalnica river basin

\section{CONCLUSION}

The results of this study indicated that the lithological distribution of 69 analyzed elements is based on the dominant occurrence of three geochemical associations as follows: $\mathrm{Ca}-\mathrm{K}-\mathrm{Mg}-\mathrm{Na}-$ Ba-Li-Mn-Sr-V, Al-Fe and Sb. For the first and dominant Factor 1, higher standard values were 
obtained in Zone III and Zone IV, so the majority are transported downriver. The occurrence of trace elements in significant concentrations is correlated with the specific geology of the sub regions in the investigated area. The enrichments of these elements in four of the tributaries (Zletovska, Lakavica, Ovčepolska and Kamenica rivers) basically influence their occurrence in the Bregalnica river. Trace elements are specifically correlated with Factors 2 and 3. The Al-Fe geochemical association is specific to the Lakavica river. This factor is related with dominant occurrence of some trace elements REEs, such as: $\mathrm{Br}-\mathrm{Ce}-\mathrm{Cu}-\mathrm{Cr}-\mathrm{Cs}-\mathrm{Dy}-\mathrm{Er}-$ Eu-Gd-I-La-Mo-Nd-Nb-Re-Sm-Tl-W-Y-Zr. Furthermore, the area of the Lakavica river is characterized by a very specific geochemistry. The third factor, presenting the dominance of antimony shows statistical correlation in the $\mathrm{Pb}-\mathrm{Zn}$ mineralization areas (Kamenica and Zletovska rivers). This factor correlates with the occurrence of As-Au-Be$\mathrm{Cd}-\mathrm{Co}-\mathrm{Ce}-\mathrm{Ni}-\mathrm{Pb}-\mathrm{Zn}$. Potentially toxic heavy metals were determined at levels below the maximum allowed concentration for the specific class for water quality. Only the lead and zinc concentrations exceeded the maximum allowed concentration in accordance with the relevant classification in the area of the $\mathrm{Pb}-\mathrm{Zn}$ mineralization and exploitation (Kamenica river).

\section{REFERENCES}

[1] G. W. Van Loon, S. J. Duffy, Environmental Chemistry: A global perspective, Oxford University Press, New York, 2000.

[2] Y. Yi, Z. Yang, S. Zhang, Ecological risk assessment of heavy metals in sediment and human health risk assessment of heavy metals in fishes in the middle and lower reaches of the Yangtze river basin, Environ. Pollut., 159, 2575-2585 (2011).

[3] V. Furtula, H. Osachoff, G. Derksen, H. Juahir, A. Colodey, P. Chambers, Inorganic nitrogen, sterols and bacterial source tracking as tools to characterize water quality and possible contamination sources in surface water, Water Res., 46, 1079-1092 (2012).

[4] R. I. S. Alves, C. F. Sampaio, M, Nadal, M. Schuhmacher, J. L. Domingo, S. I. Segura-Muñoz, Metal concentrations in surface water and sediments from Pardo River, Brazil: Human health risks, Environ. Res., 133, 149-155 (2014).

[5] J. Gaillardet, J. Viers, B. Dupre, Trace elements in river waters. In: J. I Dreaver, H. D. Holland, K. K. Turekian (Eds.), Treatise on Geochemistry. Surface and Groundwater Weathering and Soils, Elsevier-Pergamon, Oxford 2003, pp. 225-272.

[6] H. E. Taylor, R. C. Antweiler, D. A. Roth, C. N. Alpers, P. Dileanis, Selected trace elements in the Sacramento River, California: occurrence and distribution, Archiv. Environ. Contam. Toxicol., 62, 557-569 (2012).
[7] K. G. Bhattacharyya, N. Kapil, Impact of urbanization on the quality of water in a natural reservoir: a case study with the Deepor Beel in Guwahati City, India, Water Environ. J., 24, 83-96 (2010).

[8] J. Das, Geochemistry of trace elements in the ground water of Cuttack City, India, Water Air Soil Pollut., 14, 129-140 (2003).

[9] N. Haloi, H. Sarma, Heavy metal contaminations in the groundwater of Brahmaputra flood plain: an assessment of water quality in Barpeta District, Assam (India), Environ. Monit. Assess., 184, 6229-6237 (2012).

[10] S. Li, Q. Zhang, Risk assessment and seasonal variations of dissolved trace elements and heavy metals in the Upper Han River, China, J. Hazardous Materials, 181, 1051-1058 (2010).

[11] S. Su, R. Xiao, X. Mi, X. Xu, Z. Zhang, J. Wu, Spatial determinants of hazardous chemicals in surface water of Qiantang River, China, Ecol. Indic., 24, 375-381 (2013).

[12] H. E. Taylor, 2001, Inductively Coupled Plasma - Mass Spectrometry: Practices and Techniques, Academic Press, New York, 2001.

[13] T. Stafilov, R. Šajn, Z. Pančevski, B. Boev, M. V. Frontasyeva, L. Strelkova, Geochemical Atlas of Veles and the Environs, Faculty of Natural Sciences and Mathematics, Skopje, 2008.

[14] T. Stafilov, R. Šajn, B. Boev, J. Cvetković, D. Mukaetov, M. Andreevski, Geochemical Atlas of Kavadarci and the Environs, Faculty of Natural Sciences and Mathematics, Skopje, 2008.

[15] T. Stafilov, B. Balabanova, R. Šajn, K. Bačeva, B. Boev. Geochemical Atlas of Radoviš and the Environs and the Distribution of Heavy Metals in the Air, Faculty of Natural Sciences and Mathematics, Skopje, 2010.

[16] T. Stafilov, R. Šajn, F. Sulejmani, K. Bačeva, Geochemical Atlas of Kičevo and the Environs, Faculty of Natural Sciences and Mathematics, Skopje, 2011.

[17] T. Stafilov, B. Balabanova, R. Šajn, Geochemical Atlas of the Region of the Bregalnica River Basin, Faculty of Natural Sciences and Mathematics, Skopje, 2014.

[18] B. Balabanova, T. Stafilov, K. Bačeva, R. Šajn, Biomonitoring of atmospheric pollution with heavy metals in the copper mine vicinity located near Radoviš, Republic of Macedonia, J. Environ. Sci. Health, Part A, 45, 1504-1518 (2010).

[19] B. Balabanova, T. Stafilov, R. Šajn, K. Bačeva, Distribution of chemical elements in attic dust as reflection of lithology and anthropogenic influence in the vicinity of copper mine and flotation, Arch. Environ. Contam. Toxicol., 61, 173-184 (2011).

[20] B. Balabanova, T. Stafilov, R. Šajn, K. Bačeva, Characterisation of heavy metals in lichen species Hypogymnia physodes and Evernia prunastri due to biomonitoring of air pollution in the vicinity of copper mine, Inter. J. Environ. Res., 6, 779-794 (2012).

[21] B. Balabanova, T. Stafilov, R. Šajn, K. Bačeva, Spatial distribution and characterization of some toxic metals and lithogenic elements in top soil and subsoil from copper mine environs, Inter. J. Environ. Protec., 3, 1-9 (2013).

[22] S. Ilić-Popov, T. Stafilov, R. Šajn, C. Tănăselia, K. Bačeva, Applying of factor analyses for determination of trace elements distribution in water from River Vardar 
and its tributaries, Macedonia/Greece, Scientific World Journal, 2014, 1-11 (2014).

[23] T. Stafilov, Environmental pollution with heavy metals in the Republic of Macedonia, Contributions, Section of Natural, Mathematical and Biotechnical Sciences, MASA, 35, 81-119 (2014).

[24] A. Lazarevski, Climate in Macedonia, Kultura, Skopje, 1993

[25] ISO 5667-4:1987 Water quality - Sampling - Part 4: Guidance on sampling from lakes, natural and manmade, International Organization for Standardization, Geneva, Switzerland.

[26] G. E. P. Box, D. R. Cox, An analysis of transformations, J. R. Soc. Series B Stat. Methodol., 26(2), 211-252 (1964).

[27] G. A. F. Seber, Multivariate observation, John Wiley \& Sons Inc., Hoboken, New Jersey, 2008.

[28] G. Žibret, R. Šajn, Hunting for geochemical associations of elements: factor analysis and self-organizing maps, Math. Geosci., 42, 681-703 (2010).

[29] N. Dumurdžanov, T. Serafimovski, B. C. Burchfiel, Evolution of the Neogene-Pleistocene basins of Macedonia. Geological Society of America, Digital Map and Chart Series 1, 2004.

[30] T. Rakićević, N. Dumurdžanov, M. Petkovski, Basic Geological Map of SFRJ, sheet Štip, M 1:100,000 (map \& interpreter), Federal Geological Survey, Belgrade, 1968.

[31] Official Gazette of the Republic of Macedonia, Regulation on classification of waters in the Republic of Macedonia, No. 118, Skopje, 1999.
[32] C. Abesser, R. Robinson, Mobilisation of iron and manganese from sediments of a Scottish upland reservoir, $J$. Limnol., 69, 42-53 (2010).

[33] R. C. Antweiler, H. E. Taylor, C. N. Alpers, Distribution and geochemistry of selected trace elements in the Sacramento River near Keswick Reservoir, Chemical Geology, 298-299, 70-78 (2012).

[34] J. J. Corbi, S. Trivinho-Strixino, A. Dos Santos, Environmental evaluation of metals in sediments and dragonflies due to sugar cane cultivation in neotropical streams, Water Air Soil Pollut., 195, 325-333 (2008).

[35] V. Bhardwaj, D. S. Singh, A. K. Singh, Environmental repercussions of cane-sugar industries on the Chhoti Gandak river basin, Ganga Plain, India, Environ. Monit. Assess., 171, 321-344 (2010).

[36] T. Serafimovski, V. Stefanova, A. V. Volkov, Dwarf copper-gold porphyry deposits of the Buchim-Damjan Borov Dol ore district, Republic of Macedonia (FYROM), Geol. Ore Deposit., 52, 179-195 (2010).

[37] S. Lehmann, J. Barcikowski, A. von Quadt, D. Gallhofer, I. Peytcheva, C. A. Heinrich, T. Serafimovski, Geochronology, geochemistry and isotope tracing of the Oligocene magmatism of the Bučim-Damjan-Borov Dol ore district: Implications for timing, duration and source of the magmatism, Lithos, 180-181, 216-233 (2013).

[38] B. Balabanova, T. Stafilov, R. Šajn, Lithogenic distribution of rare earth elements in automorphic and alluvial soils from Bregalnica river basin, Maced. J. Chem. Chem. Eng., 34 (1), 201-212 (2015). 